\title{
Immunotherapy Moves to the Early-Stage Setting in Non-Small Cell Lung Cancer: Emerging Evidence and the Role of Biomarkers
}

\author{
Xabier Mielgo-Rubio ${ }^{1, *}$, Virginia Calvo ${ }^{2}$, Javier Luna ${ }^{3}$, Jordi Remon ${ }^{4}$ (D), Margarita Martín ${ }^{5}$, \\ Pedro Berraondo ${ }^{6}{ }^{\mathbb{D}}$, José Ramón Jarabo ${ }^{7}$, Oliver Higuera ${ }^{8}$, Esther Conde ${ }^{9}$, Javier De Castro ${ }^{8} \mathbb{D}$, \\ Mariano Provencio ${ }^{2}$, Florentino Hernando Trancho ${ }^{7}$, Fernando López-Ríos ${ }^{9}$ and \\ Felipe Couñago 10,11,12
}

1 Department of Medical Oncology, Hospital Universitario Fundación Alcorcón, Budapest 1 Alcorcón, 28922 Madrid, Spain

2 Department of Medical Oncology, Puerta de Hierro Hospital, Joaquín Rodrigo 1, Majadahonda, 28222 Madrid, Spain; virginia.calvo@salud.madrid.org (V.C.); mariano.provencio@salud.madrid.org (M.P.)

3 Department of Radiation Oncology, Fundacion Jimenez Diaz, Oncohealth Institute, Avda. Reyes Católicos 2, 28040 Madrid, Spain; jluna@fjd.es

4 Department of Medical Oncology, Centro Integral Oncológico Clara Campal (HM-CIOCC), Hospital HM Delfos, HM Hospitales, 08023 Barcelona, Spain; jordi.remon@delfos.cat

5 Department of Radiation Oncology, Ramón y Cajal University Hospital, M-607, 100, 28034 Madrid, Spain; margarita.martin@salud.madrid.org

6 Division of Immunology and Immunotherapy, Cima Universidad de Navarra and Instituto de Investigacion Sanitaria de Navarra (IdISNA), 31008 Pamplona, Spain; pberraondol@unav.es

7 Department of Thoracic Surgery, Hospital Clínico San Carlos, Calle del Prof Martín Lagos, s/n, 28040 Madrid, Spain; joseramon.jarabo@salud.madrid.org (J.R.J.);

florentino.hernando@salud.madrid.org (F.H.T.)

8 Department of Medical Oncology, Hospital Universitario La Paz, Paseo de la Castellana 261, 28046 Madrid, Spain; oliver.higuera@salud.madrid.org (O.H.); javier.decastro@salud.madrid.org (J.D.C.)

9 Pathology-Targeted Therapies Laboratory, HM Hospitales, 28015 Madrid, Spain; econde@hmhospitales.com (E.C.); flopezrios@hmhospitales.com (F.L.-R.)

10 Department of Radiation Oncology, Hospital Universitario Quirónsalud Madrid, Pozuelo de Alarcón, 28223 Madrid, Spain; felipe.counago@quironsalud.es

11 Department of Radiation Oncology, Hospital La Luz, 28003 Madrid, Spain

12 Department of Radiation Oncology, Universidad Europea de Madrid, Villaviciosa de Odón, 28670 Madrid, Spain

* Correspondence: xabier.mielgo.rubio@urjc.es; Tel.: +34-605-751-636

Received: 16 October 2020; Accepted: 17 November 2020; Published: 20 November 2020

Simple Summary: In recent years there has been a trend towards an increase in the proportion of non-small cell lung cancer patients diagnosed with localized stage instead of advanced. However, 5-year survival rates continue to be low, even among patients diagnosed at early stages. In recent years major advances have been made in the treatment of advanced NSCLC, in large part due to the irruption of immunotherapy. PD-1 axis blocking-based immunotherapy is already a well-established standard of care treatment for patients with advances NSCLC, in frontline setting and in pretreated patients. Our greatest challenge now is to move the benefit of immunotherapy to patients with early-stage NSCLC so as to increase 5-year survival rate. The aim of this manuscript is to make a comprehensive review of available evidence, make a critical review of the results of published and ongoing studies, and analyze the role of biomarkers, main areas of controversy and future challenges.

Abstract: Despite numerous advances in targeted therapy and immunotherapy in the last decade, lung cancer continues to present the highest mortality rate of all cancers. Targeted therapy based on specific genomic alterations, together with PD-1 and CTLA-4 axis blocking-based immunotherapy, 
have significantly improved survival in advanced non-small cell lung cancer (NSCLC) and both therapies are now well-established in this clinical setting. However, it is time for immunotherapy to be applied in patients with early-stage disease, which would be an important qualitative leap in the treatment of lung cancer patients with curative intent. Preliminary data from a multitude of studies are highly promising, but therapeutic decision-making should be guided by an understanding of the molecular features of the tumour and host. In the present review, we discuss the most recently published studies and ongoing clinical trials, controversies, future challenges and the role of biomarkers in the selection of best therapeutic options.

Keywords: immunotherapy; early-stage; non-small cell lung cancer; biomarkers; PD-1; nivolumab; pembrolizumab; atezolizumab; durvalumab

\section{Introduction}

Lung cancer is the most common type of cancer worldwide, with 2.1 million new cases annually, and also the leading cause of cancer-related mortality (1.8 million deaths in 2018) [1]. Non-small cell lung carcinoma (NSCLC) accounts for approximately $85 \%$ of lung tumours. NSCLC has a poor prognosis, posing a serious health risk even in patients with early stage disease, with a low 5-year survival rate [2]. Although most patients are diagnosed with advanced disease (48.7\% in 2015 according to the SEER database), better diagnostic techniques and widespread screening may be the key to achieving an earlier diagnosis. In fact, there has been a clear trend in recent years towards an increase in the percentage of patients diagnosed with localized NSCLC, from 16.6\% in 1988 to $23.6 \%$ in 2015 (SEER database) [3].

Major advances have been made in the treatment of NSCLC in recent years, leading to a significant improvement in survival outcomes [4]. Most of these treatment advances have occurred in advanced disease due to the discovery of a number of oncogenic mutations (unrelated to tobacco use) responsible for some lung tumours. The discovery of these molecular pathways has led to the development of targeted anti-cancer drug therapies, with excellent results in terms of antitumour efficacy. The first oncogenic mutation identified, in the year 2004, was the epidermal growth factor receptor (EGFR) mutation $[5,6]$. However, numerous other mutations have been discovered, including ALK, ROS1, BRAF, MET, RET, and NTRK, among others [7]. Indeed, the improved survival outcomes in patients with lung cancer observed through the year 2016 correspond closely with the timing of regulatory approval of targeted therapies. In the coming years, additional improvements in survival outcomes are expected due to the introduction of immunotherapy, which has been used in clinical practice to treat advanced NSCLC since 2015 with PD-1 and CTLA-4 axis blocking-based monoclonal antibodies (mAbs). Together, targeted therapies and immunotherapy represent a major paradigm shift in the treatment of NSCLC [8]. (Table 1).

Table 1. Characteristics of Immune Checkpoints Inhibitors discussed in the manuscript.

\begin{tabular}{cccc}
\hline Name & Antibody Type & Mechanism of Action & Company \\
\hline Nivolumab & Human IgG4 & PD-1 inhibitor & Bristol-Myers Squibb \\
Pembrolizumab & Humanized IgG4 & PD-1 inhibitor & MSD \\
Atezolizumab & Humanized IgG1k & PD-L1 inhibitor & Roche/Genentech \\
Durvalumab & Human IgG1k & PD-L1 inhibitor & Medimmune/Astra Zeneca \\
Ipilimumab & Human IgG1 & CTLA-4 inhibitor & Bristol-Myers Squibb \\
\hline
\end{tabular}

Advanced NSCLC refers to those patients with metastatic NSCLC and treatment objectives focus on prolonging survival and improving quality of life of these patients. On the other hand, early-stage NSCLC comprises those tumours between stages I and III of the TNM classification system developed by the American Joint Committee on Cancer (AJCC) and treatment aim is curative. We need to add surgery and/or radiotherapy to achieve this goal so far in early-NCSLC. 
At present, immunotherapy is approved only for the treatment of advanced NSCLC, with the notable exception of consolidation durvalumab, which has been approved to treat unresectable locally-advanced NSCLC after radical chemoradiation (CRT). In advanced setting, immune checkpoint inhibitors (ICI) based immunotherapy has demonstrated overall survival (OS) improvement both in palliative first line and second line setting. In unresectable stage III NSCLC, consolidation durvalumab improved disease-free survival (DFS) and OS after radical CRT.

Antitumour effect of ICI-based immunotherapy is based on enhancing the ability of the host's immune system to recognize tumour cells as strange to trigger an antitumour immune response that ends up eliminating the tumour cells. The presence of tumour cells with neoantigens different from the normal origin cells are present from the beginning of tumour growth, both in early and advanced stages, so there is biological rational for immunotherapy to be also effective in early stages.

Numerous studies are already underway to assess the role of these treatments in early-stage NSCLC, with early results supporting this therapeutic approach in these patients, which is particularly relevant given that early treatment could have the greatest impact in terms of reducing mortality rates [9]. Presently, our greatest challenge is to make the demonstrated benefit of immunotherapy in advanced disease available to patients with localized or locoregional disease [10]. In the present article, we review the data supporting the implementation of immunotherapy in early-stage NSCLC. We discuss the results of published studies as well as clinical trials currently in progress and role of biomarkers. Finally, we critical review the main areas of controversy and future challenges.

\section{Immune Checkpoint Inhibitors in Early NSCLC}

In every step of the tumorigenesis process, tumours must overcome the body's antitumour effector immune response. To avoid the effects of the immune system, tumours deploy a multitude of immune escape mechanisms. Recent clinical evidence shows the relevance of one of these mechanisms present in multiple cancer types, including NSCLC: the PD-1/PD-L1 pathway. Inflammatory cytokines such as interferon-gamma induce PD-L1 expression, both in tumour cells and in myeloid-derived cells infiltrating the tumour microenvironment. Interaction between PD-L1 and PD-1, expressed on activated T lymphocytes, limits the proliferation, activation, and effector mechanisms of tumour-specific T lymphocytes. The remarkable clinical efficacy of mAbs targeting PD-1 or PD-L1 has led to the approval of these agents as monotherapy or combination therapy in different stages of NSCLC. However, primary and secondary resistance is frequent, thus limiting the long-term clinical benefit of these treatment modalities [11]. However, combination therapies designed to synergize with anti-PD-1/PD-L1 mAbs can overcome these resistance mechanisms. The antitumour efficacy of mAbs targeting the PD-1 pathways relies on a pre-existing antitumour effector immune response. Therefore, therapeutic strategies that prime an antitumour immune response may synergize with anti-PD-1/PD-L1 mAbs. In this regard, CTLA-4 stands out as a critical immune checkpoint during the priming phase of the immune response. CTLA-4 prevents CD28 signalling required for efficient activation of effector T lymphocytes [12]. The combination of anti-PD-1 and anti-CTLA-4 promotes an immune response characterized by an increase of CD4+ICOS+T lymphocytes and a different CD8+ population than the exhausted CD8+PD-1+TIM-3+LAG3+T lymphocytes that dominate the response after anti-PD1 monotherapy [13].

Conventional cancer therapies can complement anti-PD-1/PD-L1 mAbs, thus providing early control of disease progression. However, in addition to early clinical control, surgery, chemotherapy, and radiotherapy also enhance the priming phase of the immune response, and can, therefore, synergize with anti-PD-1 mAbs.

Regarding surgery, preclinical research has demonstrated the superiority of neoadjuvant immunotherapy over adjuvant immunotherapy. Neoadjuvant immunotherapy is characterized by an increase in tumour-specific CD8+cells, suggesting a role in $\mathrm{T}$ cell priming or in $\mathrm{T}$ cell migration into the tumour, although further research is needed to decipher immune mechanisms implicated. Many more preclinical studies have evaluated the potential of chemotherapy and radiotherapy combined with immunostimulatory monoclonal antibodies. Several chemotherapy and radiotherapy regimens induce 
immunogenic cell death, characterized by tumour-associated antigen release in the context of danger signals that promote the activation of the cross-presenting dendritic cells, characterized by the expression of the Batf3 transcription factor. In addition, elimination of immunosuppressive immune populations, such as $\mathrm{T}$ regulatory cells and myeloid-derived suppressor cells, has also been frequently reported for a variety of chemotherapy and radiotherapy regimens. In the case of radiotherapy (RT), a robust abscopal effect has been observed in preclinical models using ablative hypofractionated radiation dose schedules, such as $8 \mathrm{~Gy} \times 3$ fractions. These RT regimens allow cytoplasmic DNA accumulation and subsequent activation of the cGAS-STING (stimulator of interferon genes) pathway, leading to high type I interferon production. In contrast, a single dose of $20 \mathrm{~Gy}$ induced the expression of the exonuclease Trex, which prevents the accumulation of cytoplasmic DNA and induction of immune response priming [14].

\section{Immunotherapy in Early-Stage NSCLC: Combining it with Surgery and Radiotherapy}

\subsection{Resectable/Potentially-Resectable Early-Stage NSCLC}

\subsubsection{Current and Emerging Evidence with ICIs}

Surgery is the main treatment option in patients with resectable localized NSCLC, with 5-year OS rates ranging from 36\% (stage IIIA, with N2 detected incidentally during surgery) to 92\% (stage IA1) [15]. Numerous studies have been performed in an effort to improve these outcomes by adding adjuvant treatment, with the first of these studies conducted in the 1980s with contradictory findings. A meta-analysis carried out by the Non-Small Cell Lung Cancer Collaborative Group (NSCLC-CG), published in 1995, evaluated 14 studies (4,357 patients) comparing surgery alone to surgery followed by chemotherapy (CT) [16]. After publication of that meta-analysis, several randomised trials were initiated. The largest and most important study of adjuvant therapy, which changed the treatment of these patients, was the International Adjuvant Lung Cancer (IALT) study, published in 2004. That trial demonstrated an improvement in OS in patients who received adjuvant CT (cisplatin doublet) [17]. The results of the LACE (Lung Adjuvant Cisplatin Evaluation) meta-analysis, which evaluated five studies (ALPI, IALT, BLT, JBR.10, and ANITA) comprising 4584 patients, were published in 2008 [18], showing that patients who received adjuvant CT had a 5.4\% improvement in OS at 5 years (median follow-up: 5.2 years) and an $11 \%$ reduction in the risk of death (HR $0.89,95 \%$ CI $0.82-0.96, p=0.0043$ ).

Survival rates in patients surgically-treated for NSCLC remain poor, underscoring the need for novel therapeutic strategies. Multiple clinical trials are currently underway in early-stage NSCLC to assess the role of ICIs in both adjuvant and neoadjuvant settings. Initially, several vaccines were evaluated, with one study demonstrating that immunotherapy against the tumor-specific MAGE-A3 antigen in melanoma showed anti-tumour activity [19]. Based on these findings, it was proposed to evaluate this vaccine in lung cancer. Adjuvant MAGE-A3 immunotherapy was first evaluated in a randomised phase 2 trial in patients with completely-resected stage IB-II NSCLC [20]. In a subsequent phase 3 trial (MAGRIT) [21], 2227 MAGE-A3 positive patients with completely-resected stage IB, II, and IIIA NSCLC were randomised, in a 2:1 ratio, to receive the MAGE-A3 vaccine or placebo. However, no significant differences were observed in DFS rates (60.5 vs. 57.9 months, HR 1.02). Currently, five phase 3 clinical trials are underway to evaluate the role of immunotherapy in patients with completely-resected NSCLC. In those trials, more than 4500 patients with stage IB-IIIA NSCLC have been randomised (regardless of PD-L1 status) to receive one year of ICI or placebo (PEARLS, BR31, CANOPY-A) or one year of ICI vs. observation (ANVIL and IMpower-010) after standard CT, if indicated. The main outcome measure in all five trials is DFS (Table 2).

Neoadjuvant and adjuvant therapy have a comparable impact on OS outcomes [22], although adjuvant therapy is supported by a larger body of evidence. Neoadjuvant therapy has numerous advantages, and it is an excellent clinical scenario to identify clinical and molecular markers. Several phase 3 trials have demonstrated that platinum-based induction CT improves OS in NSCLC, including patients with stage IIIA (N2) disease [23,24]. These results were confirmed in a subsequent meta-analysis [22]. 
Table 2. Ongoing phase 3 clinical trials with adjuvant ICIs.

\begin{tabular}{|c|c|c|c|c|c|c|c|c|}
\hline Name & $\begin{array}{c}\text { Trial } \\
\text { Registration } \\
\text { Number }\end{array}$ & Phase & Stage & $\mathbf{N}$ & Study Arm & $\begin{array}{l}\text { Control } \\
\text { Arm }\end{array}$ & $\begin{array}{l}\text { Primary } \\
\text { Objective }\end{array}$ & $\begin{array}{c}\text { Trial } \\
\text { Completion } \\
\text { Date }\end{array}$ \\
\hline $\begin{array}{c}\text { PEARLS/ } \\
\text { KEYNOTE-091 }\end{array}$ & NCT02504372 & 3 & IB $(\geq 4 \mathrm{~cm})$-IIIA & 1080 & $\begin{array}{c}\text { Pembrolizumab } \\
200 \text { mg IV every } 3 \\
\text { weeks for one year }\end{array}$ & $\begin{array}{l}\text { Placebo, } \\
\text { one year }\end{array}$ & DFS & 2024 \\
\hline BR31/LINC & NCT02273375 & 3 & IB ( $\geq 4 \mathrm{~cm})$-IIIA & 1360 & $\begin{array}{c}\text { Durvalumab } \\
10 \mathrm{mg} / \mathrm{kg} \text { IV every } 2 \\
\text { weeks for } 6 \text { months } \\
20 \mathrm{mg} / \mathrm{kg} \text { IV every } 4 \\
\text { weeks for } 6 \text { months }\end{array}$ & $\begin{array}{l}\text { Placebo, } \\
\text { one year }\end{array}$ & $\begin{array}{c}\text { DFS } \\
\text { PD-L1+ } \\
\text { DFS global }\end{array}$ & 2024 \\
\hline ANVIL & NCT02595944 & 3 & IB $(\geq 4 \mathrm{~cm})$-IIIA & 903 & $\begin{array}{l}\text { Nivolumab } 240 \mathrm{mg} \text { IV } \\
\text { every } 2 \text { weeks for } 1 \text { year }\end{array}$ & Observation & $\begin{array}{l}\text { DFS } \\
\text { OS }\end{array}$ & 2024 \\
\hline IMpower 010 & NCT02486718 & 3 & IB $(\geq 4 \mathrm{~cm})$-IIIA & 1280 & $\begin{array}{c}\text { Atezolizumab } \\
1200 \mathrm{mg} \text { IV every } \\
3 \text { weeks for one year }\end{array}$ & Observation & $\begin{array}{c}\text { DFS II-IIIA } \\
\text { DFS II-IIIA } \\
\text { PD-L1+ } \\
\text { DFS ITT }\end{array}$ & 2027 \\
\hline
\end{tabular}

ICI: immune checkpoint inhibitor; IV: intravenous; SC, subcutaneous; DFS: disease-free survival; OS: overall survival; ITT: intention-to-treat.

Immunotherapy administered in combination with neoadjuvant therapy could potentially induce an antitumour immune response that persists beyond surgery, thus preventing recurrent disease. Indeed, various studies have demonstrated the feasibility and safety of ICI as a neoadjuvant therapy in NSCLC (Table 3).

In the trial carried out by Forde et al. (NCT02259621) [25], administration of nivolumab was not associated with a delay in surgery nor an increase in perioperative complications. In that trial, treatment-related adverse events (AE) of any grade were observed in $23 \%(5 / 22)$ of patients, with only one $\mathrm{AE} \geq$ grade 3 . In addition, major pathological response (MPR) was observed regardless of PD-L1 expression. The tumour mutational burden (TMB) was predictive of pathological response. At a median follow-up of 30 months, the median recurrence-free survival (RFS) had not been reached, with a 24-month RFS of $69 \%$ (95\% CI: 51-93) [26]. In the LCMC3 trial (NCT02927301) [27] one patient developed a grade $5 \mathrm{AE}$ (not treatment related) while 16 presented grade $3 / 4 \mathrm{AEs}$ (three of which were treatment-related). Surgery was delayed in one patient due to grade 3 immune-related pneumonitis. The NEOSTAR study (NCT03158129) is a phase 2 trial involving patients with stage I-IIIA (N2 only) NSCLC. Patients received three doses of nivolumab $3 \mathrm{mg} / \mathrm{kg}$ IV every 2 weeks or nivolumab $3 \mathrm{mg} / \mathrm{kg}$ IV every 2 weeks for three cycles, plus ipilimumab $1 \mathrm{mg} / \mathrm{kg}$ on day 1 followed by surgery. AEs were observed in $4 \%$ of patients, including 2 cases of bronchopleural fistula and 8 air leaks [28].

Studies demonstrating that chemoimmunotherapy is superior to $\mathrm{CT}$ alone in patients with metastatic NSCLC have prompted interest in evaluating the role of chemoimmunotherapy as neoadjuvant therapy in early-stage NSCLC followed by surgery. The NADIM study (NCT03081689) is an open-label, phase 2, single-arm clinical trial to evaluate the safety and efficacy of neoadjuvant CT (paclitaxel $200 \mathrm{mg} / \mathrm{m}^{2}$ + carboplatin AUC 6 IV every 3 weeks) plus nivolumab (360 mg IV), 3 cycles, followed by surgery and one year of adjuvant nivolumab (240 mg IV every 2 weeks for 4 months and $480 \mathrm{mg}$ IV every 4 weeks for 8 months) in 46 patients with resectable stage IIIA (N2 or T4) NSCLC [29]. The primary endpoint is progression-free survival (PFS) at 24 months. The latest results of that trial were presented at the 2019 World Conference on Lung Cancer (WCLC), with the highest pathological complete response ( $\mathrm{pCR}$ ) rate observed to date in this patient population. At a median follow-up of 17 months, the 18-month PFS and OS rates were $81 \%$ and $91 \%$, respectively [30]. A new randomised phase 2 clinical trial is underway (currently recruiting) to compare the same treatment regimen (neoadjuvant $\mathrm{CT}$ plus nivolumab followed by surgery) plus adjuvant nivolumab for 6 months or standard CT alone (NADIM II; NCT03838159). Shu et al. (NCT02716038) conducted an open-label, multicenter, single-arm phase 2 trial to evaluate combined CT treatment (carboplatin AUC 5 IV every 
3 weeks plus nab-paclitaxel $100 \mathrm{mg} / \mathrm{m}^{2}$ on days 1,8 , and 15) and atezolizumab $1200 \mathrm{mg}$ IV every 3 weeks for 4 cycles. The primary endpoint was MPR. Thirty patients were included and $17(57 \%)$ achieved a MPR [31]. The most common grade 3-4 AEs were neutropenia, elevated transaminases, and thrombopenia. Several other studies are currently evaluating the role of ICIs with or without CT in the neoadjuvant setting (Table 4).

Table 3. Clinical trials of neoadjuvant ICI with or without chemotherapy.

\begin{tabular}{|c|c|c|c|c|c|c|c|c|c|c|c|}
\hline Name & $\begin{array}{l}\text { Registration } \\
\text { Number }\end{array}$ & Phase & Stage & $\mathbf{N}$ & Resected & Treatment & $\begin{array}{l}\text { Primary } \\
\text { Objective }\end{array}$ & $\begin{array}{c}\text { MPR } \\
(\%)\end{array}$ & $\begin{array}{l}\text { Pcr } \\
(\%)\end{array}$ & $\underset{(\%)}{\text { Surgery }}$ & $\begin{array}{l}\text { Trial } \\
\text { Completion } \\
\text { Date }\end{array}$ \\
\hline SKCCC-JHU [25] & NCT02259621 & 2 & IB-IIIA & 22 & 21 & $\begin{array}{l}\text { Nivolumab } 3 \mathrm{mg} / \mathrm{kg} \text { IV } \\
\text { every } 2 \text { weeks, } 2 \text { cycles }\end{array}$ & $\begin{array}{c}\text { Safety } \\
\text { Feasibility }\end{array}$ & 45 & 15 & 95 & 2023 \\
\hline LCMC3 [27] & NCT02927301 & 2 & $\begin{array}{l}\text { IB-IIIB } \\
\text { (T3N2) }\end{array}$ & 180 & 101 & $\begin{array}{l}\text { Atezolizumab } 1200 \mathrm{mg} \\
\text { IV every } 3 \text { weeks, } \\
2 \text { cycles }\end{array}$ & MPR & 19 & 5 & 89 & 2020 \\
\hline NEOSTAR [28] & NCT03158129 & 2 & $\begin{array}{l}\text { I-IIIA } \\
\text { (N2 } \\
\text { only) }\end{array}$ & 88 & $\begin{array}{l}\text { N: } 23 \\
\text { NI: } 21\end{array}$ & $\begin{array}{c}\mathrm{N}: 3 \mathrm{mg} / \mathrm{kg} \text { IV every } \\
2 \text { weeks, } 3 \text { cycles } \\
\text { NI: Nivolumab } 3 \mathrm{mg} / \mathrm{kg} \\
\text { IV every } 2 \text { weeks, } \\
3 \text { cycles and Ipilimumab } \\
1 \mathrm{mg} / \mathrm{kg} \text { on day } 1\end{array}$ & MPR & $\begin{array}{l}\text { N: } 17 \\
\text { NI: } 33\end{array}$ & $\begin{array}{l}\text { N: } 9 \\
\text { NI: } 29\end{array}$ & $\begin{array}{l}\text { N: } 96 \\
\text { NI: } 81\end{array}$ & 2021 \\
\hline NADIM [29] & NCT03081689 & 2 & $\begin{array}{l}\text { IIIA } \\
\text { (N2 or } \\
\text { T4) }\end{array}$ & 46 & 41 & $\begin{array}{l}\mathrm{CT}+\text { Nivolumab } 360 \mathrm{mg} \\
\text { IV every } 3 \text { weeks, } \\
3 \text { cycles-Postoperative } \\
\text { nivolumab for one year }\end{array}$ & $\begin{array}{l}\text { PFS at } 24 \\
\text { months }\end{array}$ & 83 & 59 & 89 & 2021 \\
\hline $\begin{array}{c}\text { Columbia } \\
\text { University [31] }\end{array}$ & NCT02716038 & 2 & IB-IIIA & 30 & 11 & $\begin{array}{l}\text { CT+Atezolizumab } \\
1200 \text { mg IV every } \\
3 \text { weeks, } 4 \text { cycles }\end{array}$ & MPR & 57 & 33 & 87 & 2020 \\
\hline
\end{tabular}

ICI, immune checkpoint inhibitors; N: Nivolumab; I: Ipilimumab; CT: chemotherapy; IV: intravenous; MPR: major pathological response; pCR: pathological complete response; PFS: progression-free survival.

Table 4. Clinical trials ongoing with neo/adjuvant ICI with or without chemotherapy.

\begin{tabular}{|c|c|c|c|c|c|c|c|c|}
\hline Trial Name & $\begin{array}{l}\text { Registration } \\
\text { Number }\end{array}$ & Phase & Stage & $\mathbf{N}$ & Study Arm & Control Arm & $\begin{array}{l}\text { Primary } \\
\text { Objective }\end{array}$ & $\begin{array}{c}\text { Estimated } \\
\text { Completion } \\
\text { Date }\end{array}$ \\
\hline KEYNOTE-671 [32] & NCT03425643 & 3 & IIB-IIIA & 786 & $\begin{array}{c}\text { CT }(\text { CG or CP) + } \\
\text { pembrolizumab } 200 \text { mg IV } \\
\text { every } 3 \text { weeks, } \\
4 \text { cycles-pembrolizumab } \\
200 \text { mg IV every } 3 \text { weeks } \\
\text { postoperatively }\end{array}$ & $\begin{array}{l}\mathrm{CT}+\text { placebo - } \\
\text { and postoperative } \\
\text { placebo }\end{array}$ & $\begin{array}{l}\text { DFS, } \\
\text { OS }\end{array}$ & 2024 \\
\hline CheckMate 816 [33] & NCT02998528 & 3 & IB-IIIA & 350 & $\begin{array}{l}\mathrm{CT}+\text { nivolumab } 360 \mathrm{mg} \text { IV } \\
\text { every } 3 \text { weeks, } 3 \text { cycles }\end{array}$ & CT, 3 cycles & $\begin{array}{l}\text { DFS, } \\
\text { pCR }\end{array}$ & 2020 \\
\hline IMpower 030 [34] & NCT03456063 & 3 & $\begin{array}{l}\text { II-IIIA-IIIB } \\
\text { (T3N2) }\end{array}$ & 374 & $\begin{array}{l}\mathrm{CT}+\text { atezolizumab } 1200 \mathrm{mg} \text { IV } \\
\text { every } 3 \text { weeks, } 4 \text { cycles - } \\
\text { Atezolizumab } 1200 \mathrm{mg} \text { IV } \\
\text { every } 3 \text { weeks postoperatively }\end{array}$ & $\begin{array}{l}\mathrm{CT}+\text { placebo - } \\
\text { and postoperative } \\
\text { placebo }\end{array}$ & MPR & 2024 \\
\hline Checkmate 77T & NCT04025879 & 3 & II-IIIB & 452 & $\begin{array}{c}\text { CT + nivolumab } 360 \mathrm{mg} \text { IV } \\
\text { every } 3 \text { weeks, } 4 \text { cycles - } \\
\text { nivolumab } 480 \text { mg IV every } \\
4 \text { weeks for one year } \\
\text { postoperatively }\end{array}$ & $\begin{array}{c}\mathrm{CT}+\text { placebo - } \\
\text { and postoperative } \\
\text { placebo }\end{array}$ & DFS & 2023 \\
\hline AEGEAN & NCT03800134 & 3 & $\begin{array}{l}\text { IIA-IIIA-IIIB } \\
\quad(\mathrm{N} 2)\end{array}$ & 300 & $\begin{array}{c}\text { CT + Durvalumab } 1500 \mathrm{mg} \text { IV } \\
\text { every } 3 \text { weeks, } 4 \text { cycles } \\
\text {-Durvalumab } 1500 \text { mg IV every } \\
4 \text { weeks, } 12 \text { cycles }\end{array}$ & $\begin{array}{l}\mathrm{CT}+\text { placebo - } \\
\text { and postoperative } \\
\text { placebo }\end{array}$ & MPR & 2024 \\
\hline SAKK 16/14 & NCT02572843 & 2 & IIIA (N2) & 68 & $\begin{array}{c}\text { CT, } 2 \text { cycles-Durvalumab } \\
750 \mathrm{mg}, 2 \text { cycles-durvalumab } \\
750 \mathrm{mg} \text { for } 1 \text { year }\end{array}$ & & DFS & 2021 \\
\hline NADIM 2 & NCT03838159 & 2 & IIIA-IIIB & 90 & $\begin{array}{l}\mathrm{CT}+\text { nivolumab } 360 \mathrm{mg} \text { IV } \\
\text { every } 3 \text { weeks, } \\
3 \text { cycles-nivolumab } 480 \mathrm{mg} \text { IV } \\
\text { every } 4 \text { weeks for } 6 \text { months } \\
\text { postoperatively }\end{array}$ & $\mathrm{CT}$ & $\mathrm{pCR}$ & 2022 \\
\hline
\end{tabular}

ICI, immune checkpoint inhibitors; CT: chemotherapy; CG: cisplatin-gemcitabine; CP: cisplatin-pemetrexed; IV: intravenous; MPR: major pathological response; pCR: pathological complete response; DFS: disease-free survival OS: overall survival. 


\subsubsection{Role of SBRT and ICIs}

Stereotactic body radiation therapy (SBRT) has become the standard treatment for inoperable early-stage NSCLC (ES-NSCLC) [35]. SBRT is defined by the American College of Radiology (ACR) and the American Society for Radiation Oncology (ASTRO) as the use of very high radiation doses ( $>6$ Gy/fraction) delivered in few fractions $(\leq 5)$ [36], an approach that has unique radiobiological characteristics capable of generating a strong tumour response. SBRT involves the delivery of highly conformal radiation to the tumour, with control of respiratory and tumour movement and daily image acquisition, which makes it a highly efficacious treatment [37,38].

Various trials have reported excellent results with SBRT in ES-NSCLC. The phase 2 RTOG 0236 trial in patients with inoperable ES-NSCLC yielded an impressive 5-year local tumour control rate of 93\% [39,40], with only minimal pulmonary toxicity [41]. Regional and distant relapse rates can be as high as $30 \%$ in patients with ES-NSCLC $[40,42,43]$. We still need to define the patients who would be good candidates for systemic treatment plus SBRT due to a high risk of recurrence based on histological findings [44], pretreatment standardized uptake values (SUV) on 18F-FDG PET imaging [45], and the gene expression profile [46].

Most patients with ES-NSCLC who are candidates for SBRT (but not surgery) cannot safely receive CT. Moreover, the combination of adjuvant CT plus SBRT has not shown positive results in frail patients with ES-NSCLC who have multiple underlying pathologies [47]. The combination of immunotherapy—which is generally better tolerated than CT [48]—and SBRT has been evaluated primarily in patients with metastatic disease, with promising clinical results [49,50]. In addition to better tolerance, SBRT + immunotherapy offers important synergistic benefits, as SBRT can produce local and systemic antitumour effects mediated by the immune system, a phenomenon known as the abscopal effect [51], which is stronger when these two treatments are combined [49]. SBRT can reduce the tumour burden, thus permitting greater activation of $\mathrm{T}$ lymphocytes to destroy micrometastatic disease [52]. RT has shown other immunomodulatory effects that could also be synergistic when combined with immunotherapy, including the following: enhanced MHC class I expression [53], which allows for better recognition of the tumour cell by T lymphocytes; upregulation of FAS receptors in the tumour cells, leading to greater infiltration of these cells by T lymphocytes [54]; increased expression of NKG2D ligands, which allows for greater action of natural killer cells [55]; and other effects currently under investigation.

Despite the proven clinical benefit of SBRT plus immunotherapy in metastatic disease, there is still no demonstrated benefit for this combined treatment in ES-NSCLC, although several phase 1/2 clinical trials are currently investigating this approach. NRG Oncology is carrying out an interesting phase 3 trial of durvalumab vs. adjuvant placebo after SBRT in patients with unresected ES-NSCLC (PACIFIC-4) [56].

Table 5 summarizes the studies that are currently underway to investigate immunotherapy combined with SBRT in early-stage NSCLC. Some of these trials are evaluated the combination of SBRT, immunotherapy, and surgery. The NCT03217071 study proposes irradiating only $50 \%$ of the tumour, which will allow us to determine the local effect of SBRT plus immunotherapy as well as its impact on distant disease. Other trials are aiming to determine the optimal SBRT dose to combine with immunotherapy, the optimal time to deliver the two treatments, and the duration of immunotherapy. For example, the University of San Diego is evaluating immunotherapy plus SBRT (4 fractions of $12.5 \mathrm{~Gy}$ and 5 fractions of $10 \mathrm{~Gy}$ ). In that trial, anti-PD-L1 therapy is administered 24 to $48 \mathrm{~h}$ before RT. In the trial being performed by the Tibor Rubin VA Medical Center and the Davis University of California, SBRT is administered with the third cycle. In the various trials, the duration of immunotherapy ranges from 3 and 24 months. 
Table 5. Current clinical trials evaluating the combination of immunotherapy and SBRT.

\begin{tabular}{|c|c|c|c|c|c|c|}
\hline Study Name & Study Type & Type of Patients & Treatment & $\begin{array}{c}\text { Primary } \\
\text { Objective }\end{array}$ & $\begin{array}{l}\text { Secondary } \\
\text { Objectives }\end{array}$ & $\begin{array}{l}\text { Current } \\
\text { Status }\end{array}$ \\
\hline $\begin{array}{c}\text { STILE } \\
\text { NCT03383302 }\end{array}$ & $\begin{array}{c}\text { Phase 2, single arm, } \\
\text { multicentric trial } \\
\text { (Sponsor: Royal Marsden } \\
\text { NHS Foundation Trust) }\end{array}$ & $\begin{array}{l}\text { Stages I-II } \\
\text { NSCLC }\end{array}$ & $\begin{array}{c}\text { - SBRT (54 Gy in } 3 \mathrm{fr} \text { of } 18 \mathrm{~Gy} \\
\text { or } 55 \text { Gy in } 5 \mathrm{fr} \text { of } 11 \mathrm{~Gy} \text { ) } \\
\text { - Sequential nivolumab, } \\
1 \text { year }\end{array}$ & $\begin{array}{l}\text {-Evaluation of } \\
\text { lung toxicity }\end{array}$ & $\begin{array}{l}\text { - Other toxicities } \\
\text {-Local relapse } \\
\text { rates, OS, DFS }\end{array}$ & Recruiting \\
\hline NCT03110978 & $\begin{array}{l}\text { Phase 2, single arm trial } \\
\text { (Sponsor: M.D. Anderson } \\
\text { Cancer Center) }\end{array}$ & $\begin{array}{l}\text { Stage I-IIA } \\
\text { NSCLC }\end{array}$ & $\begin{array}{l}\text {-SBRT (50 Gy in } 4 \text { fr or } 70 \text { Gy } \\
\text { in } 10 \mathrm{fr} \text { ) } \\
\text {-Nivolumab } 12 \text { weeks, started } \\
\text { with 1st fraction of SBRT }\end{array}$ & -DFS & $\begin{array}{c}\text {-OS } \\
\text {-Adverse events } \\
\text {-Analysis of } \\
\text { immunological } \\
\text { markers }\end{array}$ & Recruiting \\
\hline NCT03446911 & $\begin{array}{l}\text { Randomised clinical trial } \\
\text { (Sponsor: VU University } \\
\text { Medical Center) }\end{array}$ & Stage I NSCLC & $\begin{array}{l}\text {-ARM 1: SBRT with } 2 \text { cycles } \\
\text { of pembrolizumab started on } \\
\text { the 1st day of RT followed by } \\
\text { lobectomy } \\
\text {-ARM 2: SBRT without } \\
\text { pembrolizumab followed by } \\
\text { lobectomy }\end{array}$ & $\begin{array}{l}\text {-Incidence and } \\
\text { severity of } \\
\text { adverse effects }\end{array}$ & $\begin{array}{l}\text {-Expression of } \\
\text { PD-1, PDL-1, } \\
\text { CD4, among } \\
\text { others }\end{array}$ & Unknown \\
\hline NCT02444741 & $\begin{array}{l}\text { Randomised phase } 1 / 2 \\
\text { clinical trial (Sponsor: } \\
\text { M.D. Anderson } \\
\text { Cancer Center) }\end{array}$ & $\begin{array}{l}\text { NSCLC: early } \\
\text { and advanced } \\
\text { stages }\end{array}$ & $\begin{array}{c}\text { Distinct groups included } \\
\text { with varying combinations } \\
\text { between pembrolizumab, } \\
\text { SBRT or hypofractionated RT } \\
\text { Pembrolizumab is started } \\
\text { before SBRT }(4 \mathrm{fr}) \text { or } \\
\text { hypofractionated RT ( } 15 \mathrm{fr}) \text {. } \\
\text { It is administered every } 21 \\
\text { days until reach a maximum } \\
\text { of } 16 \text { cycles }\end{array}$ & $\begin{array}{l}\text {-Response rate } \\
\text { and determination } \\
\text { of radiological } \\
\text { response } \\
\text {-Toxicity } \\
\text { Maximum tolerate } \\
\text { dose of } \\
\text { pembrolizumab }\end{array}$ & $\begin{array}{l}\text {-DFS } \\
\text {-OS }\end{array}$ & Recruiting \\
\hline $\begin{array}{l}\text { SWOG S1914 } \\
\text { NCT04214262 }\end{array}$ & $\begin{array}{l}\text { Phase } 3 \text { clinical trial } \\
\text { (Sponsor: National } \\
\text { Cancer Institute (NCI) }\end{array}$ & $\begin{array}{l}\text { Stages I-IIA } \\
\text { NSCLC }\end{array}$ & $\begin{array}{l}\text {-ARM 1: Atezolizumab } \\
8 \text { cycles every } 21 \text { days. SBRT } \\
\text { ( } 3-5 \text { fr) with cycle } 3 \text { of } \\
\text { atezolizumab } \\
\text {-ARM } 2 \text { : SBRT }(3-5 \text { fr) at } \\
21 \text { days post- randomisation } \\
\text { without atezolizumab }\end{array}$ & - OS & $\begin{array}{c}\text {-SLP } \\
\text {-Adverse effects }\end{array}$ & Recruiting \\
\hline $\begin{array}{c}\text { PACIFIC-4/ } \\
\text { RTOG-3515 } \\
\text { NCT03833154 }\end{array}$ & $\begin{array}{l}\text { Phase } 3 \text { multicentre, } \\
\text { double-blind clinical trial } \\
\text { (Sponsor: Astra Zeneca) }\end{array}$ & $\begin{array}{l}\text { NSCLC stages } \\
\text { I-II with } \\
\text { negative nodes }\end{array}$ & $\begin{array}{l}\text {-ARM 1: Durvalumab } \\
1500 \text { mg every } 4 \text { weeks up to } \\
24 \text { months of treatment or } \\
\text { progression. SBRT } \\
\text { (from 3-8 fr) } \\
\text { ARM 2: Placebo an SBRT } \\
\text { (from 3-8 fr) }\end{array}$ & -DFS & $\begin{array}{c}\text {-OS } \\
\text {-Lung } \\
\text { cancer-specific } \\
\text { mortality } \\
\text {-Others }\end{array}$ & Recruiting \\
\hline $\begin{array}{c}\text { ASTEROID } \\
\text { NCT03446547 }\end{array}$ & $\begin{array}{l}\text { Phase } 2 \text { multicentre, } \\
\text { randomised clinical trial } \\
\text { (Sponsor: Vastra } \\
\text { Gotaland Region) }\end{array}$ & NSCLCT1-2N0M0 & $\begin{array}{l}\text {-Arm 1: SBRT (3-4 fr) } \\
\text {-Arm 2: SBRT }(3-4 \mathrm{fr}) \\
\text { followed by durvalumab } \\
1500 \text { mg every } 4 \text { weeks } \\
12 \text { months }\end{array}$ & -TTP & $\begin{array}{c}\text {-OS } \\
\text {-Control local }\end{array}$ & Recruiting \\
\hline
\end{tabular}

Fr: fractions; OS: Overall survival; DFS: disease-free survival; PFS SLP: progression-free survival; TTP: Time to

progression; RT, external beam radiotherapy.

\subsection{Unresectable Stage III NSCLC}

One-third of NSCLC patients have stage III disease at diagnosis. In these patients, the standard of care (SoC) is concurrent platinum-based chemotherapy and radiation [57]. Unfortunately, OS remains poor, with a median OS ranging from 20 to 26 months [58,59] and 3- and 5-year OS of $30 \%$ and $15 \%$, respectively $[57,58]$. Moreover, none of the novel strategies employed to date-such as adding induction or consolidation CT, the incorporation of EGFR inhibitors, or higher dose RT-have been shown to improve the OS versus SoC [60].

RT may increase the production and presentation of tumour antigens, which may enhance the antitumour immune responses elicited by ICIs [61]. Preclinical data support the rationale for combining both strategies [62], leading to the launch of various trials to assess this hypothesis. The phase 3 PACIFIC trial assessed the role of durvalumab $(10 \mathrm{mg} / \mathrm{kg}$ Q2W) versus placebo as consolidation treatment for one year in 713 patients without progression after CRT. Durvalumab significantly achieved both co-primary endpoints, PFS (17.2 vs. 5.6 months, HR 0.55, 95\% CI: 0.44-67, $p<0.0001$ ) [63] and OS (47.5 vs. 29.1 months, HR $0.71,95 \%$ CI: $0.57-0.88$ ), with a 3 -year OS of $55 \%$ vs. $44 \%$ and $4-$ year OS of $49.6 \%$ vs. $36.3 \%$, respectively [64,65]. Durvalumab also improved the response rate (RR) (30\% vs. 17.8\%, $p<0.001)$ [63] and decreased the incidence of new brain metastases (6.3\% vs. $11.8 \%$, respectively) [66]. Safety was similar in the durvalumab and placebo arms (grade $\geq 3$ AEs: $30.5 \%$ vs. $26.1 \%$, including pneumonitis, $3.6 \%$ vs. $2.4 \%$ ), 
as were treatment discontinuation rates $(15.4 \%$ vs. $9.8 \%)[63,66]$. Moreover, the benefit of durvalumab was achieved without a detrimental effect on patient-reported outcomes [67]. Although risk of pneumonitis in the PACIFIC trial was low and not associated with baseline respiratory disorders, prior RT dose, or prior cisplatin or carboplatin use [68], careful patient selection and active surveillance is required, as real-world studies indicate a grade 3 pneumonitis rate of $14.3 \%$ [69].

Enrolment in the PACIFIC trial was not restricted to any specific PD-L1 expression threshold level, and PD-L1 status was not mandatory for inclusion. A prespecified exploratory analysis assessed the benefit of durvalumab according to PD-L1 expression $\geq 25 \%$ (by SP263 IHC assay). Of the $63 \%$ of patients assessable for PD-L1 expression, 35\% and 67\% had PD-L1 $\geq 25 \%$ or PD-L1 $\geq 1 \%$, respectively. In patients with PD-L1 $\geq 25 \%$, durvalumab improved PFS (HR 0.41; 95\%CI: 0.26-0.65) and OS (HR: 0.50, 95\%CI: 0.30-0.83), whereas in those with PD-L1 < 25\%, it improved PFS (HR 0.59, 95\% CI: 0.43-0.82) but not OS (HR: 0.89, 95\% CI: 0.63-1.25) [70]. The European Medicines Agency (EMA) requested an additional exploratory post-hoc analysis using a 1\% cut-off for PD-L1 expression. Although durvalumab improved PFS and OS in tumours with PD-L1 $\geq 1 \%$, in the 148 patients with PD-L1 < 1\%, durvalumab neither improved PFS (HR 0.73; 95\%CI: 0.48-1.11) nor OS (HR: 1.14, 95\%CI: 0.71-1.84) [69]. Based on these data, the Food and Drug Administration (FDA) approved durvalumab as a new SoC regardless PD-L1 expression in February 2018, whereas the EMA approval in September 2018 was limited to tumours with PD-L1 $\geq 1 \%$. The efficacy of durvalumab is currently being evaluated in a real-world setting in the PACIFIC-R trial (NCT03798535) [70]. Similarly, the ongoing phase 3 PACIFIC5 trial (NCT03706690) is evaluating a flat dose of durvalumab (1500 mg Q4W) compared to placebo after concurrent or sequential CRT. PD-L1 status by SP263 is mandatory in this trial. The phase 2 PACIFIC6 trial (NCT03693300) is assessing durvalumab (1500 mg Q4W) after sequential treatment. A planned interim analysis from the BTCRC-LUN 16-081 phase 2 trial comparing consolidative treatment after CRT with nivolumab plus ipilimumab versus nivolumab resulted in a higher percentage of grade 3 AEs (44\% vs. $32 \%$, including pneumonitis $16 \%$ vs. $4 \%$ ), which resulted in a higher rate of treatment discontinuation (40\% vs. $16 \%$ ) [71].

The combination of pembrolizumab and CRT was evaluated in the phase 2 LUN 14-179 [72] and KEYNOTE-799 trials [73], atezolizumab in the DETERRED trial [74], and nivolumab in the NICOLAS trial [75,76], all with promising results (Table 6). Finally, the ongoing phase 3 PACIFIC2 trial (NCT03519971) is assessing durvalumab administered concurrently with definitive CRT, but the control arm is only CRT alone, which is less than ideal as the future challenge is to assess the best treatment approach, either concurrent ICI versus consolidation, and to assess the best consolidation approach (ICI vs. ICI plus ICI). The phase 3 Checkmate 73L (NCT04026412) trial is evaluating all of these treatment approaches. Another important question is the optimal treatment duration for consolidation therapy, especially as only $43 \%$ of patients enrolled in PACIFIC trial were able to complete the planned one-year of therapy [68]. Finally the role of predictive biomarkers, such as PD-L1 expression, and prospective validation of minimal residual disease assessed by dynamic circulating tumour DNA (ctDNA) may help to personalise consolidation ICI strategy after CRT [77].

Table 6. Summary of the efficacy of immune checkpoint inhibitors in stage III NSCLC.

\begin{tabular}{ccccc}
\hline Trial & Schedule & N & PFS & OS \\
\hline PACIFIC [63,65], & CRT Durvalumab & 713 & $17.2 \mathrm{~m}$ & $\begin{array}{c}\text { 3-y OS: } 55 \% \\
\text { mOS: } 49.6 \%\end{array}$ \\
& & & & 3-y OS: $49 \%$ \\
LUN 14-179 [72] & CRT + P P & 92 & $18.7 \mathrm{~m}$. & mOS: $36 \mathrm{~m}$ \\
KEYNOTE 799 [73] & CT CRT + P P & 165 & 6-m PFS: $80 \%$ & \\
NICOLAS [75,76] & CRT+N N & 79 & $12.4 \mathrm{~m}$ & 1-y OS: $79 \%$ \\
DETERRED [74] & CRT CT + A A & 10 & $18.6 \mathrm{~m}$ & 22.8 m \\
& A + CRTCT + A A & 30 & $13.2 \mathrm{~m}$ & NR \\
\hline
\end{tabular}

$\mathrm{N}=$ number of patients; PFS: progression-free survival; OS: overall survival; $\mathrm{m}$ : months; $\mathrm{y}$, year; CRT: concurrent chemoradiation; CT: chemotherapy; P: Pembrolizumab; A: Atezolizumab; N: nivolumab; NR: not reached; mOS: median overall survival. 


\section{Future Challenges for ICI in Early-Stage Disease}

\subsection{Optimal Treatment Duration}

The optimal duration of neoadjuvant or adjuvant treatment with ICIs is unknown. At present, treatment duration is based on data from clinical trials that have evaluated neoadjuvant and adjuvant therapy in NSCLC. Treatment duration is an important consideration due to its potential impact on patient quality of life and with respect to the cost. Currently, there is no evidence of any correlation between longer treatment duration and increased survival in advanced NSCLC [78-81]. Indeed, exploratory analyses have found long-term NSCLC survivors even among patients who did not complete all ICI cycles, although the available data are limited [79,82].

In terms of neoadjuvant therapy, the trials that have evaluated platinum-based induction CT combined with third-generation CT agents have generally administered three cycles of neoadjuvant CT, with one study using four cycles [83]. For this reason, three induction cycles have been traditionally administered in clinical practice. Similarly, most studies that include ICIs in the neoadjuvant therapy regimen also administer three cycles, although several have used 2 or 4 cycles $[25,28,29,31,84]$. Consequently, the number of cycles administered in clinical practice generally corresponds to the cycles used in the trial on which the selected treatment regimen is based. Several of the studies that have evaluated neoadjuvant immunotherapy [29,84] (in monotherapy or in combination with CT), as well as the ongoing phase 2 and 3 trials, generally administer adjuvant ICIs for one year after surgery $[32-34,85,86]$. However, there is no concrete evidence to support this strategy, which is why it should be evaluated prospectively in randomised trials. In addition, the duration of adjuvant ICI presents other challenges in terms of treatment compliance and costs. Similarly, the optimal duration of adjuvant ICI treatment in patients who have not undergone prior induction therapy is not known. Most studies that have evaluated adjuvant CT have administered four cycles; however, the protocols of studies currently underway to assess adjuvant ICI as monotherapy without prior induction generally stipulate one year of ICI administration after standard adjuvant CT, with the exception of the BR.31/LINC trial, in which the duration is 6 months. Another unresolved question is whether it would be possible, in certain cases, to shorten the duration of adjuvant ICI in patients who have received neoadjuvant ICI therapy, or whether adjuvant ICI could be obviated in patients who achieve a pCR. New biomarkers, such as ctDNA, could potentially facilitate treatment decision-making in this clinical scenario [77].

\subsection{Optimal Timing of Surgery}

No evidence is available about the optimal timing of surgery after neoadjuvant treatment. The interval between the first neoadjuvant dose and surgery has varied in the different clinical trials. Thus, surgery was performed two weeks after the second cycle in the first trial of nivolumab, 3-4 weeks after the 21st day of the third cycle in the NADIM trial, and on day 29 after the 2nd cycle of pembrolizumab in the NEONUM trial. However, experimental analyses suggest that the efficacy of neoadjuvant immunotherapy in terms of survival may be dependent on an optimal duration between the first dose and resection [87]. The only study correlating the timing between neoadjuvant therapy and surgery is the study conducted by Gao et al. [88]. Those authors found that patients with resectable N2-IIIA who underwent surgery within 6 weeks after completing neoadjuvant CRT had significantly better OS than those who underwent surgery after six weeks. Traditionally, the optimal timing of surgery is between 4 and 6 weeks after completion of neoadjuvant therapy, based on histological changes secondary to radiation. However, this should not be extrapolated to new therapies without further, specific clinical research.

\subsection{Surgical Challenges after Neoadjuvant Immunotherapy: New Patterns of Response}

One difficulty that surgeons may face in patients who receive neoadjuvant ICI therapy prior to surgery is the response to immunotherapy, such as the contradictory response between the primary tumour and the hilar and mediastinal lymph nodes (probably due to genomic and immunological 
heterogeneity), in which an initial "tumour flare", caused by immune cell infiltration, is observed. In these cases, it can be difficult to distinguish between pseudo-progression and real tumour progression. If this response is not interpreted correctly, surgery might be erroneously ruled out [89], a phenomenon that has been observed in up to $11 \%$ of patients with NSCLC who present nodal immune flare [90]. Although rare, hyperprogressive response patterns have been described in advanced disease [91]. This pattern could theoretically also occur in localized disease, although no cases have been reported to date. Consequently, the use of new radiological techniques, such as multiparametric magnetic resonance imaging [92] and/or positron-emission computed tomography (PET-CT), is important to better assess T-cell response [93] to differentiate between tumour response and progression in these clinical scenarios. Finally, evaluation of ctDNA levels [94] to assess tumour dynamics may also play a role in the future.

\subsection{Challenges for Surgery with Neoadjuvant Immunotherapy: Surgical Difficulties}

Most trials to date have focused on the complete resection rate, even though they agree that surgical morbidity and mortality do not differ from series without neoadjuvant therapies [29]. It is well-established among thoracic surgeons that surgical resection is technically more demanding after induction therapy, although it is difficult to quantify the degree of difficulty. Induction therapies induce tumour necrosis and the formation of scar tissue. The most challenging steps in the surgical procedure involve exposing the vascular structures to be sectioned and dissection of the hilar and mediastinal lymph nodes. The resection approach (i.e., minimally invasive vs. open) is a suboptimal way of evaluating the technical difficulty [95]. Changes in pulmonary structures after CT have been histologically documented [96]. Moreover, interstitial damage leading to a worsening in pulmonary tests directly related to higher postoperative complications has also been demonstrated [97,98]. In this regard, if we could predict the effects of new drugs, we could exclude patients with limited pulmonary function. Finally, it is essential to underscore the importance of using the term "complete resection" properly [99]. Complete resection requires the following: (i) free resection margins confirmed microscopically; (ii) systematic nodal dissection or lobe-specific systematic nodal dissection; (iii) absence of extracapsular nodal extension of the tumour; and (iv) the highest mediastinal node removed must be negative. If these four criteria cannot be met, then the resection must be considered uncertain. Complete resection defined in this way should be an inclusion criterion in clinical trials performed to evaluate surgical patients. For this reason, the involvement of thoracic surgeons in the design and development of these trials is mandatory.

\subsection{Role of Biomarkers in Resectable NSCLC}

Biomarker studies in early-stage tumours are approximately similar to those in advanced tumours. In advances setting most developed biomarkers are PD-L1 expression and TMB, and are the only ones that we use in daily clinical practice, but there are several biomarkers that have been or that are being studied. Neoadjuvant trials are an ideal setting for exploring predictive biomarkers and same markers as in advanced disease are being explored in resectable NSCLC, that include four major categories: tumour cell-associated biomarkers as PD-L1 expression and TMB, tumor microenvironment-related biomarkers, liquid biopsy-related biomarkers and host-related markers. We need to take into account that biomarkers in early-stage NSCLC have only been explored preliminarly and that we cannot confirm their value so far and even compare to their role in advanced disease. PD-L1 expression and TMB have not shown a consistent association with response to neoadjuvant immunotherapy. In the study by Forde and colleagues [25], tumours demonstrating a MPR to nivolumab were infiltrated with large numbers of lymphocytes and macrophages, and these changes were seen in both PD-L1-positive and negative tumours. As expected, tumours with a MPR had a higher TMB and a systematic increase in the number of T-cell clones in the tumour and peripheral blood. Interestingly, there were no alterations in immune-related genes (including CD274, PDCD1, CTLA4, B2M, and HLA) in patients with or without a MPR. In a phase 3 trial conducted by Shu and colleagues, PD-L1 expression did not 
appear to be predictive of a treatment benefit, and patients with STK11 tumour mutations did not have significant radiographic or pathological responses [31].

Both the NEOSTAR and LCMC3 trials found that immunotherapy showed activity (measured by MPR) against early-stage NSCLC. PD-L1 was positively correlated with MPR in NEOSTAR, but neither PD-L1 nor TMB correlated with MPR in LCMC3 [28,31]. Radiographic response was positively correlated with MPR in both studies.

T-cell expansion and ctDNA are emerging biomarkers that may prove useful in the future. In the CheckMate 159 trial, T-cell receptor (TCR) repertoire was significantly expanded in patients who achieved MPR and ctDNA clearance prior to surgery was detected in all patients who achieved a reduction $\geq 30 \%$ [100]. Furthermore, peripheral expansion of tumour-specific T-cells and long-term persistence were associated with longer DFS. In the NEOSTAR trial, a higher pretreatment TCR clonality in the blood was associated with a lower percentage of residual viable tumour at surgery in both treatment arms [101]. In the LCMC3 trial, the biomarker analysis based on paired peripheral blood samples showed significant increases from baseline in CD8+ T cells, mature NK cells, late-activated CD16+/CD56+ NK cells, CD16+ NK cells, and Th1 response-related dendritic cells. Those who did not achieve MPR showed significant increases in late-activated NK cells, a monocytic myeloid cell subpopulation, and a Th2- and Th17-response-related dendritic cell population. In the NADIM trial, a greater decrease in the platelets-to-lymphocytes ratio (PLR) post-treatment was associated with pCR ( $\geq 10 \%$ RVT). Moreover, higher pretreatment expression of PD-1 in CD4 T-cells and reduced activation on CD4 T and NK cells post-treatment are associated with pCR [102].

\subsection{The Role of SBRT in the ICI Strategy}

In early stage, non-operable NSCLC without nodal involvement, SBRT is the RT modality of choice. However, although SBRT achieves a local control rate of approximately $90 \%$, lymph node and distant relapse rates range from $25 \%$ to $35 \%$ [39,40]. For this reason, proposals have been made to intensity treatment by offering systemic therapy in patients at high risk of nodal involvement or distant spread. Given the highly immunogenic nature of SBRT, together with the results achieved by combining SBRT and immunotherapy in metastatic patients and the better tolerance of immunotherapy compared to conventional CT, it would seem appropriate to offer the potential benefits of this combined therapy to patients with early stage but high risk disease: patients with micropapillary or solid histological subtypes, with a predominant mucinous component, vascular invasion, high SUV on PET-CT, and large peripheral or central cT2 tumours [44,45].

Although the tumour microenvironment is strongly immunosuppressive, administration of SBRT can alter this microenvironment, making it proinflammatory. Several studies have demonstrated that the antitumour effects of radiotherapy are at least partially based on activation of immunity [103], which produces a local anti-tumour effect, a bystander effect, and a distant effect (the abscopal effect). However, irradiation can also have an immunosuppressive effect; nodal irradiation, for example, could prevent the activation and accumulation of cytotoxic $\mathrm{T}$ lymphocytes and the adaptive immune response. In addition, high dose radiation could inhibit type I interferon, which would further support the combination of ICI with SBRT in tumours without nodal involvement, thereby avoiding nodal irradiation.

\subsection{How Can We Improve the Results of Combined Immunotherapy/RT: Dose and Fractionation}

At present, there are numerous unknowns, including the optimal dose and fractionation schedule required to achieve the immunogenic effect, the optimal manner of combining RT and immunotherapy, and how to best measure response. Golden et al. showed that immunogenic cell death depends on the dose per fraction [104,105]. Preclinical studies indicate that cell death is more likely at doses of 8-10 Gy per fraction [106], while doses greater than 15 Gy stimulate an increase in regulatory T lymphocytes (which inhibit the immune response) [107], and there is no effective immune activation at dose fractions less than 5 Gy. Thus, the preclinical data seem to indicate that there may be a dose threshold above 
which immunosuppression would prevail and below which there may be no significant immune system activation. The influence of the dose size on the emergence or not of an immune response could be explained by its effect on the STING pathway, which activates type I interferon. This pathway is a key component in the switch from the innate to adaptive immune response, since it allows for the recruitment of type 1 DCs. It is activated by the presence of DNA damaged by irradiation, in the cytosol. Vapouille-Box et al. found that TREX1, a DNA exonuclease, acts at high doses per fraction and degrades this cytosolic DNA, eliminating the stimulus for type I interferon activation [108,109], which would explain the absence of the abscopal effect at dose fractions above $15 \mathrm{~Gy}$.

The duration of the immune response could also depend on the dose per fraction. At doses of $10 \mathrm{~Gy}$, markers of immune activation are evident at $72 \mathrm{~h}$, while PD-L1 expression is reduced 6 days after administration of SBRT [110]. Hettich and colleagues found that 2 fractions of 12 Gy each induced a transient increase in CD8+ cytotoxic T lymphocytes 5-8 days after irradiation, while immunosuppressive regulatory $\mathrm{T}$ cells were dominant on days 10 to 16 [111].

\subsection{Is There Any Place for Surgery in Unresectable Stage III Disease at Present?}

Until now, only curative-intent surgery had a role in NSCLC. However, paradigms of extended and unresectable disease have changed with the introduction of targeted therapies and immunotherapy in lung cancer [112]. The way these treatments sometimes achieve control of disease has made surgery becoming a complementary tool amenable to be considered in an increasing number of patients [113]. New questions that have emerged are the need to define which patients will benefit from surgery and the optimal time to perform the resection. At present, no data is yet available to answer these questions. The study of this patient cohort has evident limitations, including the following: heterogeneity in the factors that make the disease unresectable; local invasion criteria that are highly dependent on imaging data that is often imprecise; the application of multiple different therapies (CT, targeted therapies, immunotherapy, etc.) and multiple courses of treatment before resection. As a result, prospective trials will be difficult to design and retrospective data will need to be carefully assessed. Fortunately, the available data suggest that, even though the rate of pneumonitis secondary to long-term treatment is significant, overall postoperative complication rates (morbidity and mortality) are comparable to those observed in studies that have evaluated resection after neoadjuvant treatment regimens, and thus acceptable when compared to global surgical cohorts [114]. The limited evidence suggests that patients RT could cause specific histological changes and thus this subgroup of patients should be analysed separately. In terms of the type of resection, pneumonectomy should be avoided until we have greater experience. To obtain the maximum benefit from the multidisciplinary approach, the involvement of the thoracic surgeon throughout the whole disease process is essential, even if some patients will ultimately not undergo surgery.

\subsection{Role of Biomarkers for ICI in Unresectable Localised NSCLC}

Although the PACIFIC trial was not designed to evaluate durvalumab based on archival tumour PD-L1 expression, the results of exploratory analyses support a treatment benefit for durvalumab versus placebo irrespective of archival pre-specified tumour PD-L1 expression status. In that trial, the only patients who did not benefit in terms of OS from durvalumab were those with PD-L1 expression levels $<1 \%$. However, this finding was based on an unplanned post hoc analysis with a PD-L1 cut-off level that differed from the original (25\% vs. 1\%) [69]. In the phase 2 DETERRED trial of atezolizumab with concurrent CRT, PD-L1 status was not associated with recurrence [74]. Furthermore, two patients developed a recurrence before the start of consolidation therapy: one had a KRAS/STK11 co-mutation and the other had an ALK rearrangement, a finding that suggests that molecular analysis in unresectable NSCLC would be of value to identify the patients expected to benefit or not from CRT/ICI combinations.

Moding and colleagues conducted a retrospective study to determine whether ctDNA, determine through a personalized profiling by deep sequencing (CAPP-Seq), could help to identify patients 
with NSCLC who might benefit from consolidation therapy with ICI after chemoradiation and also be used to monitor treatment response [77]. Those authors found patients with ctDNA detected after chemoradiation who then received consolidation ICIs had better PFS outcomes than patients with ctDNA (also detected post-chemoradiation) who did not receive consolidation immunotherapy. In addition, the data from that study suggest that the patterns of ctDNA levels may predict which patients are more likely to benefit from consolidation ICI: patients whose ctDNA levels begin to rise early in the consolidation ICI treatment had worse outcomes. In patients whose ctDNA levels continued to increase during the course of treatment developed progressive disease within 4.5 months of starting consolidation ICI, suggesting resistance to immunotherapy. Conversely, patients with decreasing ctDNA during consolidation ICI had good outcomes.

\section{Conclusions}

Immunotherapy and targeted therapy have revolutionized the treatment landscape in advanced NSCLC. For this reason, the role of these therapies in localised disease is current being studied, with promising results to date. However, in these early stages, administration of immunotherapy is more complex as their purpose is different, we look for the cure of the patient, so objectives are different. In this regard, surrogate markers of OS are needed to obtain more conclusive results earlier in the treatment process. In addition, we need to find the best way to combine it with radical RT and surgery, which is not an easy task, in part because there are still many unresolved questions in this area. In the adjuvant studies that are currently underway, the most common primary endpoint is DFS, rather than OS. Importantly, we lack predictive biomarkers and the optimal duration of adjuvant treatment remains unclear. We are currently awaiting the results of several trials evaluating the role of PD-1 axis blocking-based immunotherapy as an adjuvant therapy, although vaccine-based strategy failed to demonstrate survival benefit. In the neoadjuvant setting with immunotherapy, the combination of CT and immunotherapy appears to be more promising than immunotherapy alone, significantly increasing $\mathrm{pCR}$ rates. The studies conducted to date leave numerous unresolved questions, including the lack of predictive biomarkers and that we still do not know how to optimally assess radiological response or the optimal duration. However, we fully expect that ongoing trials will demonstrate a benefit for immunotherapy in early-stage disease as well. In short, it seems clear that immunotherapy (at least in patients without driver mutations) will inevitably form part of the treatment arsenal for early NSCLC in the near future based on the promising results of the studies published thus far and on the numerous trials currently in progress.

Author Contributions: X.M.-R. coordinated the review and contributed to the writing of part of the manuscript and to the reviewing process. V.C. contributed to the writing of sections of the manuscript related to adjuvant and neoadjuvant strategy with immunotherapy. J.L. contributed to the writing of sections of the manuscript related to radiotherapy. J.R. contributed to the writing of the section of the manuscript related to unresectable locally-advanced non-small cell lung cancer. M.M. contributed to the writing of sections of the manuscript related to radiotherapy. P.B. contributed to the writing of the section of the manuscript related to the immuno-biological basis of using immunotherapy in early-stages of non-small cell lung cancer. J.R.J. contributed to the writing of sections of the manuscript related to thoracic surgery issues. O.H. contributed to the writing of sections of the manuscript related to biomarkers. E.C. contributed to the writing of sections of the manuscript related to biomarkers. J.D.C. contributed to the reviewing process of the manuscript. M.P. contributed to the reviewing process of the manuscript. F.H.T. contributed to the reviewing process of the manuscript. F.L.-R. contributed to the writing of sections of the manuscript related to biomarkers and to the reviewing process. F.C. contributed as coordinator and to the reviewing process of the manuscript. All authors have read and agreed to the published version of the manuscript.

Funding: This research received no external funding.

Conflicts of Interest: Xabier Mielgo-Rubio declares the following conflicts of interest: Advisory role; BoehringerIngelheim, Astra Zeneca, Brystol Myers Squibb. Speakers' bureau; Roche, Astra Zeneca, Brystol Myers Squibb, MSD, Abbott. Research funding; Brystol Myers Squibb. Pedro Berraondo declares the following conflicts of interest: Advisory role; Onena Medicines, Ferring, Tusk, Moderna. Speakers' bureau; Bristol-Myers Squibb, MSD, Novartis, Boehringer Ingelheim, AstraZeneca. Research funding; Sanofi, Bavarian Nordic, Ferring. 


\section{References}

1. Bray, F.; Ferlay, J.; Soerjomataram, I.; Siegel, R.L.; Torre, L.A.; Jemal, A. Global cancer statistics 2018: GLOBOCAN estimates of incidence and mortality worldwide for 36 cancers in 185 countries. CA Cancer J. Clin. 2018, 68, 394-424. [CrossRef] [PubMed]

2. Rami-Porta, R.; Bolejack, V.; Crowley, J.; Ball, D.; Kim, J.; Lyons, G.; Rice, T.; Suzuki, K.; Thomas, C.F.; Travis, W.D.; et al. The IASLC Lung Cancer Staging Project: Proposals for the Revisions of the T Descriptors in the Forthcoming Eighth Edition of the TNM Classification for Lung Cancer. J. Thorac. Oncol. 2015, 10, 990-1003. [CrossRef] [PubMed]

3. Lu, T.; Yang, X.; Huang, Y.; Zhao, M.; Li, M.; Ma, K.; Yin, J.; Zhan, C.; Wang, Q. Trends in the incidence, treatment, and survival of patients with lung cancer in the last four decades. Cancer Manag. Res. 2019, 11, 943-953. [CrossRef] [PubMed]

4. Howlader, N.; Forjaz, G.; Mooradian, M.J.; Meza, R.; Kong, C.Y.; Cronin, K.A.; Mariotto, A.B.; Lowy, D.R.; Feuer, E.J. The Effect of Advances in Lung-Cancer Treatment on Population Mortality. N. Engl. J. Med. 2020, 383, 640-649. [CrossRef]

5. Lynch, T.J.; Bell, D.W.; Sordella, R.; Gurubhagavatula, S.; Okimoto, R.A.; Brannigan, B.W.; Harris, P.L.; Haserlat, S.M.; Supko, J.G.; Haluska, F.G.; et al. Activating Mutations in the Epidermal Growth Factor Receptor Underlying Responsiveness of Non-Small-Cell Lung Cancer to Gefitinib. N. Engl. J. Med. 2004, 350, 2129-2139. [CrossRef]

6. Paez, J.G.; Jänne, P.A.; Lee, J.C.; Tracy, S.; Greulich, H.; Gabriel, S.; Herman, P.; Kaye, F.J.; Lindeman, N.; Boggon, T.J.; et al. EGFR Mutations in Lung Cancer: Correlation with Clinical Response to Gefitinib Therapy. Science 2004, 304, 1497-1500. [CrossRef]

7. Reck, M.; Rabe, K.F. Precision Diagnosis and Treatment for Advanced Non-Small-Cell Lung Cancer. N. Engl. J. Med. 2017, 377, 849-861. [CrossRef]

8. Lim, S.M.; Hong, M.H.; Kim, H.R. Immunotherapy for Non-small Cell Lung Cancer: Current Landscape and Future Perspectives. Immune Netw. 2020, 20, e10. [CrossRef]

9. Planchard, D.; Popat, S.; Kerr, K.; Novello, S.; Smit, E.; Faivre-Finn, C.; Mok, T.; Reck, M.; Van Schil, P.; Hellmann, M.; et al. Metastatic non-small cell lung cancer: ESMO Clinical Practice Guidelines for diagnosis, treatment and follow-up. Ann. Oncol. 2018, 29, iv192-iv237. [CrossRef]

10. Pentheroudakis, G. Recent eUpdate to the ESMO Clinical Practice Guidelines on Early and Locally Advanced Non-Small-Cell Lung Cancer (NSCLC). Ann. Oncol. 2020, 31, 1265-1266. [CrossRef]

11. Doroshow, D.B.; Sanmamed, M.F.; Hastings, K.; Politi, K.; Rimm, D.L.; Chen, L.; Melero, I.; Schalper, K.A.; Herbst, R.S. Immunotherapy in Non-Small Cell Lung Cancer: Facts and Hopes. Clin. Cancer Res. 2019, 25, 4592-4602. [CrossRef] [PubMed]

12. Chambers, C.A.; Kuhns, M.S.; Egen, J.G.; Allison, J.P. CTLA-4-Mediated Inhibition in Regulation of T Cell Responses: Mechanisms and Manipulation in Tumour Immunotherapy. Annu. Rev. Immunol. 2001, 19, 565-594. [CrossRef] [PubMed]

13. Wei, S.C.; Anang, N.-A.A.S.; Sharma, R.; Andrews, M.C.; Reuben, A.; Levine, J.H.; Cogdill, A.P.; Mancuso, J.J.; Wargo, J.A.; Pe'Er, D.; et al. Combination anti-CTLA-4 plus anti-PD-1 checkpoint blockade utilizes cellular mechanisms partially distinct from monotherapies. Proc. Natl. Acad. Sci. USA 2019, 116, 22699-22709. [CrossRef] [PubMed]

14. Vanpouille-Box, C.; Alard, A.; Aryankalayil, M.J.; Sarfraz, Y.; Diamond, J.M.; Schneider, R.J.; Inghirami, G.; Coleman, C.N.; Formenti, S.C.; DeMaria, S. DNA exonuclease Trex1 regulates radiotherapy-induced tumour immunogenicity. Nat. Commun. 2017, 8, 15618. [CrossRef] [PubMed]

15. Goldstraw, P.; Chansky, K.; Crowley, J.J.; Rami-Porta, R.; Asamura, H.; Eberhardt, W.E.E.; Nicholson, A.G.; Groome, P.; Mitchell, A.; Bolejack, V.; et al. The IASLC Lung Cancer Staging Project: Proposals for Revision of the TNM Stage Groupings in the Forthcoming (Eighth) Edition of the TNM Classification for Lung Cancer. J. Thorac. Oncol. 2016, 11, 39-51. [CrossRef] [PubMed]

16. Non-Small Cell Lung Cancer Collaborative Group. Chemotherapy in non-small cell lung cancer: A metaanalysis using updated data on individual patients from 52 randomised clinical trials. BMJ 1995, 311, 899-909. [CrossRef] 
17. Arriagada, R.; Bergman, B.; Dunant, A.; Le Chevalier, T.; Pignon, J.-P.; Vansteenkiste, J.; International Adjuvant Lung Cancer Trial Collaborative Group. Cisplatin-Based Adjuvant Chemotherapy in Patients with Completely Resected Non-Small-Cell Lung Cancer. N. Engl. J. Med. 2004, 350, 351-360. [CrossRef]

18. Pignon, J.-P.; Tribodet, H.; Scagliotti, G.V.; Douillard, J.-Y.; Shepherd, F.A.; Stephens, R.J.; Dunant, A.; Torri, V.; Rosell, R.; Seymour, L.; et al. Lung Adjuvant Cisplatin Evaluation: A Pooled Analysis by the LACE Collaborative Group. J. Clin. Oncol. 2008, 26, 3552-3559. [CrossRef]

19. Kruit, W.H.; Suciu, S.; Dreno, B.; Mortier, L.; Robert, C.; Chiarion-Sileni, V.; Maio, M.; Testori, A.; Dorval, T.; Grob, J.-J.; et al. Selection of Immunostimulant AS15 for Active Immunization With MAGE-A3 Protein: Results of a Randomized Phase II Study of the European Organisation for Research and Treatment of Cancer Melanoma Group in Metastatic Melanoma. J. Clin. Oncol. 2013, 31, 2413-2420. [CrossRef]

20. Vansteenkiste, J.; Zielinski, M.; Linder, A.; Dahabreh, J.; Gonzalez, E.E.; Malinowski, W.; Lopez-Brea, M.; Vanakesa, T.; Jassem, J.; Kalofonos, H.; et al. Adjuvant MAGE-A3 Immunotherapy in Resected Non-Small-Cell Lung Cancer: Phase II Randomized Study Results. J. Clin. Oncol. 2013, 31, 2396-2403. [CrossRef]

21. Vansteenkiste, J.; Cho, B.C.; Vanakesa, T.; De Pas, T.; Zielinski, M.; Kim, M.S.; Jassem, J.; Yoshimura, M.; Dahabreh, J.; Nakayama, H.; et al. Efficacy of the MAGE-A3 cancer immunotherapeutic as adjuvant therapy in patients with resected MAGE-A3-positive non-small-cell lung cancer (MAGRIT): A randomised, double-blind, placebo-controlled, phase 3 trial. Lancet Oncol. 2016, 17, 822-835. [CrossRef]

22. NSCLC Meta-analysis Collaborative Group. Preoperative Chemotherapy for Non-Small-Cell Lung Cancer: A Systematic Review and Meta-Analysis of Individual Participant Data. Lancet 2014, 383, 1561-1571. [CrossRef]

23. Rosell, R.; Gomez-Codina, J.; Camps, C.; Maestre, J.; Padille, J.; Canto, A.; Mate, J.L.; Li, S.; Roig, J.; Olazabal, A.; et al. A Randomized Trial Comparing Preoperative Chemotherapy Plus Surgery with Surgery Alone in Patients with Non-Small-Cell Lung Cancer. N. Engl. J. Med. 1994, 330, 153-158. [CrossRef] [PubMed]

24. Roth, J.A.; Fossella, F.; Komaki, R.; Ryan, M.B.; Putnam, J.B.; Lee, J.-S.; Dhingra, H.; De Caro, L.; Chasen, M.; McGavran, M.; et al. A Randomized Trial Comparing Perioperative Chemotherapy and Surgery with Surgery Alone in Resectable Stage III A Non-Small-Cell Lung Cancer. J. Natl. Cancer Inst. 1994, 86, 673-680. [CrossRef]

25. Forde, P.M.; Chaft, J.E.; Smith, K.N.; Anagnostou, V.; Cottrell, T.R.; Hellmann, M.D.; Zahurak, M.; Yang, S.C.; Jones, D.R.; Broderick, S.; et al. Neoadjuvant PD-1 Blockade in Resectable Lung Cancer. N. Engl. J. Med. 2018, 378, 1976-1986. [CrossRef]

26. Reuss, J.E.; Smith, K.N.; Anagnostou, V.; Zhang, J.; Zahurak, M.; Caushi, J.; Chan, H.Y.; Guo, H.; Hellmann, M.D.; Pardoll, D.M.; et al. Neoadjuvant nivolumab in resectable non-small cell lung cancer: Extended follow-up and molecular markers of response. J. Clin. Oncol. 2019, 37, 8524. [CrossRef]

27. Blumenthal, G.M.; Bunn, P.A.; Chaft, J.E.; McCoach, C.E.; Perez, E.A.; Scagliotti, G.V.; Carbone, D.P.; Aerts, H.J.; Aisner, D.L.; Bergh, J.; et al. Current Status and Future Perspectives on Neoadjuvant Therapy in Lung Cancer. J. Thorac. Oncol. 2018, 13, 1818-1831. [CrossRef]

28. Cascone, T.; William, W.N.; Weissferdt, A.; Lin, H.Y.; Leung, C.H.; Carter, B.W.; Fossella, F.V.; Mott, F.; Papadimitrakopoulou, V.; Blumenschein, J.G.R.; et al. Neoadjuvant nivolumab (N) or nivolumab plus ipilimumab (NI) for resectable non-small cell lung cancer (NSCLC): Clinical and correlative results from the NEOSTAR study. J. Clin. Oncol. 2019, 37, 8504. [CrossRef]

29. Provencio-Pulla, M.; Nadal-Alforja, E.; Cobo, M.; Insa, A.; Rivas, M.C.; Majem, M.; Rodriguez-Abreu, D.; Lopez-Vivanco, G.; Domine, M.; Morillo, E.D.B.; et al. Neoadjuvant chemo/immunotherapy for the treatment of stages IIIA resectable non-small cell lung cancer (NSCLC): A phase II multicenter exploratory study-NADIM study-SLCG. J. Clin. Oncol. 2018, 36, 8521. [CrossRef]

30. Provencio, M.; Nadal, E.; Insa, A.; Campelo, R.G.; Casal, J.; Domine, M.; Majem, M.; Rodriguez-Abreu, D.; Martinez-Marti, A.; Carpeno, J.D.C.; et al. OA13.05 NADIM Study: Updated Clinical Research and Outcomes. J. Thorac. Oncol. 2019, 14, S241. [CrossRef]

31. Shu, C.A.; Gainor, J.F.; Awad, M.M.; Chiuzan, C.; Grigg, C.M.; Pabani, A.; Garofano, R.F.; Stoopler, M.B.; Cheng, S.K.; White, A.; et al. Neoadjuvant atezolizumab and chemotherapy in patients with resectable non-small-cell lung cancer: An open-label, multicentre, single-arm, phase 2 trial. Lancet Oncol. 2020, 21, 786-795. [CrossRef]

32. Fernando, H.C.; Yang, J.; Ferraro, G.L.; Keller, S.M. Randomized, double-blind phase 3 study evaluating neoadjuvant platinum-based chemotherapy with perioperative pembrolizumab or placebo in resectable stage IIB or IIIA NSCLC: KEYNOTE-671. J. Clin. Oncol. 2018, 36, TPS8583. [CrossRef] 
33. Felip, E.; Brahmer, J.; Broderick, S.; Swanson, S.; Awad, M.; Mitsudomi, T.; Girard, N.; Kerr, K.; Spicer, J.; Cai, J.; et al. P2.16-03 CheckMate 816: A Phase 3 Trial of Neoadjuvant Nivolumab Plus Ipilimumab or Chemotherapy vs Chemotherapy in Early-Stage NSCLC. J. Thorac. Oncol. 2018, 13, S831-S832. [CrossRef]

34. Peters, S.; Kim, A.; Solomon, B.; Gandara, D.; Dziadziuszko, R.; Brunelli, A.; Garassino, M.; Reck, M.; Wang, L.; To, I.; et al. IMpower030: Phase III study evaluating neoadjuvant treatment of resectable stage II-IIIB non-small cell lung cancer (NSCLC) with atezolizumab (atezo) + chemotherapy. Ann. Oncol. 2019, 30, ii30. [CrossRef]

35. Ettinger, D.S.; Wood, D.E.; Aisner, D.L.; Akerley, W.; Bauman, J.; Chirieac, L.R.; D'Amico, T.A.; DeCamp, M.M.; Dilling, T.J.; Dobelbower, M.; et al. Non-Small Cell Lung Cancer, Version 5.2017, NCCN Clinical Practice Guidelines in Oncology. J. Natl. Compr. Cancer Netw. 2017, 15, 504-535. [CrossRef]

36. Potters, L.; Kavanagh, B.; Galvin, J.M.; Hevezi, J.M.; Janjan, N.A.; Larson, D.A.; Mehta, M.P.; Ryu, S.; Steinberg, M.; Timmerman, R.; et al. American Society for Therapeutic Radiology and Oncology (ASTRO) and American College of Radiology (ACR) Practice Guideline for the Performance of Stereotactic Body Radiation Therapy. Int. J. Radiat. Oncol. 2010, 76, 326-332. [CrossRef]

37. Caillet, V.; Booth, J.T.; Keall, P.J. IGRT and motion management during lung SBRT delivery. Phys. Med. 2017, 44, 113-122. [CrossRef]

38. Negoro, Y.; Nagata, Y.; Aoki, T.; Mizowaki, T.; Araki, N.; Takayama, K.; Kokubo, M.; Yano, S.; Koga, S.; Sasai, K.; et al. The Effectiveness of an Immobilization Device in Conformal Radiotherapy for Lung Tumour: Reduction of Respiratory Tumour Movement and Evaluation of the Daily Setup Accuracy. Int. J. Radiat. Oncol. Biol. Phys. 2001, 50, 889-898. [CrossRef]

39. Timmerman, R. Stereotactic Body Radiation Therapy for Inoperable Early Stage Lung Cancer. JAMA 2010, 303, 1070-1076. [CrossRef]

40. Timmerman, R.D.; Hu, C.; Michalski, J.M.; Bradley, J.C.; Galvin, J.; Johnstone, D.W.; Choy, H. Long-term Results of Stereotactic Body Radiation Therapy in Medically Inoperable Stage I Non-Small Cell Lung Cancer. JAMA Oncol. 2018, 4, 1287-1288. [CrossRef]

41. Stanic, S.; Paulus, R.; Timmerman, R.D.; Michalski, J.M.; Barriger, R.B.; Bezjak, A.; Videtic, G.M.; Bradley, J. No Clinically Significant Changes in Pulmonary Function Following Stereotactic Body Radiation Therapy for Early- Stage Peripheral Non-Small Cell Lung Cancer: An Analysis of RTOG 0236. Int. J. Radiat. Oncol. 2014, 88, 1092-1099. [CrossRef] [PubMed]

42. Robinson, C.G.; DeWees, T.A.; El Naqa, I.; Creach, K.M.; Olsen, J.R.; Crabtree, T.D.; Meyers, B.F.; Puri, V.; Bell, J.M.; Parikh, P.J.; et al. Patterns of Failure after Stereotactic Body Radiation Therapy or Lobar Resection for Clinical Stage I Non-Small-Cell Lung Cancer. J. Thorac. Oncol. 2013, 8, 192-201. [CrossRef] [PubMed]

43. Chi, A.; Liao, Z.; Nguyen, N.P.; Xu, J.; Stea, B.; Komaki, R. Systemic review of the patterns of failure following stereotactic body radiation therapy in early-stage non-small-cell lung cancer: Clinical implications. Radiother. Oncol. 2010, 94, 1-11. [CrossRef] [PubMed]

44. Russell, P.A.; Wainer, Z.; Wright, G.M.; Daniels, M.; Conron, M.; Williams, R.A. Does Lung Adenocarcinoma Subtype Predict Patient Survival?: A Clinicopathologic Study Based on the New International Association for the Study of Lung Cancer/American Thoracic Society/European Respiratory Society International Multidisciplinary Lung Adenocarcinoma Classification. J. Thorac. Oncol. 2011, 6, 1496-1504. [CrossRef] [PubMed]

45. Kohutek, Z.A.; Wu, A.J.; Zhang, Z.; Foster, A.; Din, S.U.; Yorke, E.D.; Downey, R.J.; Rosenzweig, K.E.; Weber, W.A.; Rimner, A. FDG-PET maximum standardized uptake value is prognostic for recurrence and survival after stereotactic body radiotherapy for non-small cell lung cancer. Lung Cancer 2015, 89, 115-120. [CrossRef] [PubMed]

46. Beer, D.G.; Kardia, S.L.; Huang, C.C.; Giordano, T.J.; Levin, A.M.; Misek, D.E.; Lin, L.; Chen, G.; Gharib, T.G.; Thomas, D.G.; et al. Gene-Expression Profiles Predict Survival of Patients with Lung Adenocarcinoma. Nat. Med. 2002, 8, 816-824. [CrossRef]

47. Foster, C.C.; Rusthoven, C.G.; Sher, D.J.; Feldman, L.; Pasquinelli, M.; Spiotto, M.T.; Koshy, M. Adjuvant chemotherapy following stereotactic body radiotherapy for early stage non-small-cell lung cancer is associated with lower overall: A National Cancer Database Analysis. Lung Cancer 2019, 130, 162-168. [CrossRef]

48. Brahmer, J.; Rodríguez-Abreu, D.; Robinson, A.G.; Hui, R.; Csőszi, T.; Fülöp, A.; Gottfried, M.; Peled, N.; Tafreshi, A.; Cuffe, S.; et al. Health-related quality-of-life results for pembrolizumab versus chemotherapy in advanced, PD-L1-positive NSCLC (KEYNOTE-024): A multicentre, international, randomised, open-label phase 3 trial. Lancet Oncol. 2017, 18, 1600-1609. [CrossRef] 
49. Shaverdian, N.; Lisberg, A.E.; Bornazyan, K.; Veruttipong, D.; Goldman, J.W.; Formenti, S.C.; Garon, E.B.; Lee, P. Previous radiotherapy and the clinical activity and toxicity of pembrolizumab in the treatment of non-small-cell lung cancer: A secondary analysis of the KEYNOTE-001 phase 1 trial. Lancet Oncol. 2017, 18, 895-903. [CrossRef]

50. Sett, R.C.; Morales-Orue, I.; Castilla-Martinez, J.; Zafra-Martin, J.; Kannemann, A.; Blanco, J.; Saez-Bravo, M.L.; Jimenez, P.C.L. Stereotactic Ablative Radiotherapy Combined with Immune Checkpoint Inhibitors Reboots the Immune Response Assisted by Immunotherapy in Metastatic Lung Cancer: A Systematic Review. Int. J. Mol. Sci. 2019, 20, 2173. [CrossRef]

51. Demaria, S.; Ng, B.; Devitt, M.L.; Babb, J.S.; Kawashima, N.; Liebes, L.; Formenti, S.C. Ionizing Radiation Inhibition of Distant Untreated Tumours (Abscopal Effect) is Immune Mediated. Int. J. Radiat. Oncol. Biol. Phys. 2004, 58, 862-870. [CrossRef] [PubMed]

52. Huang, A.C.; Postow, M.A.; Orlowski, R.J.; Mick, R.; Bengsch, B.; Manne, S.; Xu, W.; Harmon, S.; Giles, J.R.; Wenz, B.; et al. T-cell invigoration to tumour burden ratio associated with anti-PD-1 response. Nat. Cell Biol. 2017, 545, 60-65. [CrossRef] [PubMed]

53. Reits, E.A.; Hodge, J.W.; Herberts, C.A.; Groothuis, T.A.; Chakraborty, M.; Wansley, E.K.; Camphausen, K.; Luiten, R.M.; De Ru, A.H.; Neijssen, J.; et al. Radiation Modulates the Peptide Repertoire, Enhances MHC Class I Expression, and Induces Successful Antitumour Immunotherapy. J. Exp. Med. 2006, 203, 1259-1271. [CrossRef] [PubMed]

54. Chakraborty, M.; Abrams, S.I.; Coleman, C.N.; Camphausen, K.; Schlom, J.; Hodge, J.W. External Beam Radiation of Tumours Alters Phenotype of Tumour Cells to Render them Susceptible to Vaccine-Mediated T-Cell Killing. Cancer Res. 2004, 64, 4328-4337. [CrossRef]

55. Kim, J.Y.; Son, Y.O.; Park, S.W.; Bae, J.H.; Chung, J.S.; Kim, H.H.; Chung, B.S.; Kim, S.H.; Kang, C.D. Increase of NKG2D Ligands and Sensitivity to NK Cell-Mediated Cytotoxicity of Tumour Cells by Heat Shock and Ionizing Radiation. Exp. Mol. Med. 2006, 38, 474-484. [CrossRef]

56. Robinson, C.; Hu, C.; Machtay, M.; Newton, M.; Wu, K.; Barrett, K.; Dennis, P.; Bradley, J. P1.18-12 PACIFIC-4/RTOG 3515: Phase III Study of Durvalumab Following SBRT for Unresected Stage I/II, Lymph-Node Negative NSCLC. J. Thorac. Oncol. 2019, 14, S630-S631. [CrossRef]

57. Aupérin, A.; Le Péchoux, C.; Rolland, E.; Curran, W.J.; Furuse, K.; Fournel, P.; Belderbos, J.; Clamon, G.; Ulutin, H.C.; Paulus, R.; et al. Meta-Analysis of Concomitant Versus Sequential Radiochemotherapy in Locally Advanced Non-Small-Cell Lung Cancer. J. Clin. Oncol. 2010, 28, 2181-2190. [CrossRef]

58. Steuer, C.E.; Behera, M.; Ernani, V.; Higgins, K.; Saba, N.F.; Shin, D.M.; Pakkala, S.; Pillai, R.N.; Owonikoko, T.K.; Curran, W.J.; et al. Comparison of Concurrent Use of Thoracic Radiation With Either Carboplatin-Paclitaxel or Cisplatin-Etoposide for Patients With Stage III Non-Small-Cell Lung Cancer. JAMA Oncol. 2017, 3, 1120-1129. [CrossRef]

59. Senan, S.; Brade, A.; Wang, L.-H.; Vansteenkiste, J.; Dakhil, S.; Biesma, B.; Aguillo, M.M.; Aerts, J.; Govindan, R.; Rubio-Viqueira, B.; et al. PROCLAIM: Randomized Phase III Trial of Pemetrexed-Cisplatin or Etoposide-Cisplatin Plus Thoracic Radiation Therapy Followed by Consolidation Chemotherapy in Locally Advanced Nonsquamous Non-Small-Cell Lung Cancer. J. Clin. Oncol. 2016, 34, 953-962. [CrossRef]

60. Cheema, P.K.; Rothenstein, J.; Melosky, B.; Brade, A.; Hirsh, V. Perspectives on Treatment Advances for Stage III Locally Advanced Unresectable Non-Small-Cell Lung Cancer. Curr. Oncol. 2019, 26, 37-42. [CrossRef] [PubMed]

61. Tang, C.; Wang, X.; Soh, H.; Seyedin, S.; Cortez, M.A.; Krishnan, S.; Massarelli, E.; Hong, D.; Naing, A.; Diab, A.; et al. Combining Radiation and Immunotherapy: A New Systemic Therapy for Solid Tumors? Cancer Immunol. Res. 2014, 2, 831-838. [CrossRef] [PubMed]

62. Deng, L.; Liang, H.; Burnette, B.; Beckett, M.; Darga, T.; Weichselbaum, R.R.; Fu, Y.X. Irradiation and Anti-PD-L1 Treatment Synergistically Promote Antitumour Immunity in Mice. J. Clin. Investig. 2014, 124, 687-695. [CrossRef] [PubMed]

63. Antonia, S.J.; Villegas, A.; Daniel, D.; Vicente, D.; Murakami, S.; Hui, R.; Yokoi, T.; Chiappori, A.; Lee, K.H.; De Wit, M.; et al. Durvalumab after Chemoradiotherapy in Stage III Non-Small-Cell Lung Cancer. N. Engl. J. Med. 2017, 377, 1919-1929. [CrossRef]

64. Gray, J.E.; Villegas, A.; Daniel, D.; Vicente, D.; Murakami, S.; Hui, R.; Kurata, T.; Chiappori, A.; Lee, K.H.; Cho, B.C.; et al. Three-Year Overall Survival with Durvalumab after Chemoradiotherapy in Stage III NSCLC-Update from PACIFIC. J. Thorac. Oncol. 2020, 15, 288-293. [CrossRef] [PubMed] 
65. Antonia, S.J.; Villegas, A.; Daniel, D.; Vicente, D.; Murakami, S.; Hui, R.; Kurata, T.; Chiappori, A.; Lee, K.H.; De Wit, M.; et al. Overall Survival with Durvalumab after Chemoradiotherapy in Stage III NSCLC. N. Engl. J. Med. 2018, 379, 2342-2350. [CrossRef] [PubMed]

66. Hui, R.; Özgüroğlu, M.; Villegas, A.; Daniel, D.; Vicente, D.; Murakami, S.; Yokoi, T.; Chiappori, A.; Lee, K.H.; De Wit, M.; et al. Patient-reported outcomes with durvalumab after chemoradiotherapy in stage III, unresectable non-small-cell lung cancer (PACIFIC): A randomised, controlled, phase 3 study. Lancet Oncol. 2019, 20, 1670-1680. [CrossRef]

67. Vansteenkiste, J.; Naidoo, J.; Faivre-Finn, C.; Özgüroğlu, M.; Villegas, A.; Daniel, D.; Murakami, S.; Hui, R.; Lee, K.; Cho, B.; et al. MA05.02 PACIFIC Subgroup Analysis: Pneumonitis in Stage III, Unresectable NSCLC Patients Treated with Durvalumab vs. Placebo After CRT. J. Thorac. Oncol. 2018, 13, S370-S371. [CrossRef]

68. Jung, H.A.; Noh, J.M.; Sun, J.-M.; Lee, S.-H.; Ahn, J.S.; Ahn, M.-J.; Pyo, H.; Ahn, Y.C.; Park, K. Real world data of durvalumab consolidation after chemoradiotherapy in stage III non-small-cell lung cancer. Lung Cancer 2020, 146, 23-29. [CrossRef]

69. Paz-Ares, L.; Spira, A.; Raben, D.; Planchard, D.; Cho, B.; Özgüroğlu, M.; Daniel, D.; Villegas, A.; Vicente, D.; Hui, R.; et al. Outcomes with durvalumab by tumour PD-L1 expression in unresectable, stage III non-small-cell lung cancer in the PACIFIC trial. Ann. Oncol. 2020, 31, 798-806. [CrossRef]

70. Girard, N.; Mornex, F.; Christoph, D.; Fietkau, R.; Filippi, A.; Field, J.; Lopez, P.G.; McDonald, F.; Peters, S.; Klein, A.; et al. PACIFIC-R: First real-world study of patients with unresectable, stage III NSCLC treated with durvalumab after chemoradiotherapy. Ann. Oncol. 2019, 30, ii37. [CrossRef]

71. Yan, M.; Durm, G.A.; Mamdani, H.; Ernani, V.; Jabbour, S.K.; Naidoo, J.; Hrinczenko, B.; Leal, T.; Feldman, L.E.; Kloecker, G.H.; et al. Consolidation nivolumab/ipilimumab versus nivolumab following concurrent chemoradiation in patients with unresectable stage III NSCLC: A planned interim safety analysis from the BTCRC LUN 16-081 trial. J. Clin. Oncol. 2020, 38, 9010. [CrossRef]

72. Durm, G.A.; Jabbour, S.K.; Ms, S.K.A.; Liu, Z.; Sadiq, A.A.; Zon, R.T.; Jalal, S.I.; Kloecker, G.H.; Do, M.J.W.; Reckamp, K.L.; et al. A phase 2 trial of consolidation pembrolizumab following concurrent chemoradiation for patients with unresectable stage III non-small cell lung cancer: Hoosier Cancer Research Network LUN 14-179. Cancer 2020, 126, 4353-4361. [CrossRef] [PubMed]

73. Jabbour, S.K.; Lee, K.H.; Frost, N.; Kowalski, D.; Breder, V.V.; Pollock, T.; Reguart, N.; Houghton, B.; Quantin, X.; Keller, S.M.; et al. Phase II study of pembrolizumab (pembro) plus platinum doublet chemotherapy and radiotherapy as first-line therapy for unresectable, locally advanced stage III NSCLC: KEYNOTE-799. J. Clin. Oncol. 2020, 38, 9008. [CrossRef]

74. Lin, S.H.; Lin, Y.; Yao, L.; Kalhor, N.; Carter, B.W.; Altan, M.; Blumenschein, G.; Byers, L.A.; Fossella, F.; Gibbons, D.L.; et al. Phase II Trial of Concurrent Atezolizumab With Chemoradiation for Unresectable NSCLC. J. Thorac. Oncol. 2020, 15, 248-257. [CrossRef]

75. Peters, S.; Felip, E.; Dafni, U.; Belka, C.; Guckenberger, M.; Irigoyen, A.; Nadal, E.; Becker, A.; Vees, H.; Pless, M.; et al. Safety evaluation of nivolumab added concurrently to radiotherapy in a standard first line chemo-radiotherapy regimen in stage III non-small cell lung cancer-The ETOP NICOLAS trial. Lung Cancer 2019, 133, 83-87. [CrossRef]

76. Peters, S.; Felip, E.; Dafni, U.; Tufman, A.; Guckenberger, M.; Irigoyen, A.; Nadal, E.; Becker, A.; Vees, H.; Pless, M.; et al. Efficacy evaluation of concurrent nivolumab addition to a first-line, concurrent chemo-radiotherapy regimen in unresectable locally advanced NSCLC: Results from the European Thoracic Oncology Platform (ETOP 6-14) NICOLAS phase II trial. Ann. Oncol. 2019, 30, v591. [CrossRef]

77. Moding, E.J.; Liu, Y.; Nabet, B.Y.; Chabon, J.J.; Chaudhuri, A.A.; Hui, A.B.; Bonilla, R.F.; Ko, R.B.; Yoo, C.H.; Gojenola, L.; et al. Circulating Tumour DNA Dynamics Predict Benefit from Consolidation Immunotherapy in Locally Advanced Non-Small-Cell Lung Cancer. Nat. Cancer 2020, 1, 176-183. [CrossRef]

78. Vokes, E.; Ready, N.; Felip, E.; Horn, L.; Burgio, M.; Antonia, S.; Frontera, O.A.; Gettinger, S.; Holgado, E.; Spigel, D.; et al. Nivolumab versus docetaxel in previously treated advanced non-small-cell lung cancer (CheckMate 017 and CheckMate 057): 3-year update and outcomes in patients with liver metastases. Ann. Oncol. 2018, 29, 959-965. [CrossRef]

79. Gettinger, S.; Horn, L.; Jackman, D.; Spigel, D.; Antonia, S.; Hellmann, M.; Powderly, J.; Heist, R.; Sequist, L.V.; Smith, D.C.; et al. Five-Year Follow-Up of Nivolumab in Previously Treated Advanced Non-Small-Cell Lung Cancer: Results From the CA209-003 Study. J. Clin. Oncol. 2018, 36, 1675-1683. [CrossRef] 
80. Leighl, N.B.; Hellmann, M.D.; Hui, R.; Carcereny, E.; Felip, E.; Ahn, M.-J.; Eder, J.P.; Balmanoukian, A.S.; Aggarwal, C.; Horn, L.; et al. Pembrolizumab in patients with advanced non-small-cell lung cancer (KEYNOTE001): 3-year results from an open-label, phase 1 study. Lancet Respir. Med. 2019, 7, 347-357. [CrossRef]

81. Herbst, R.S.; Garon, E.B.; Kim, D.-W.; Cho, B.C.; Perez-Gracia, J.L.; Han, J.-Y.; Arvis, C.D.; Majem, M.; Forster, M.D.; Monnet, I.; et al. Long-Term Outcomes and Retreatment Among Patients With Previously Treated, Programmed Death-Ligand 1-Positive, Advanced Non-Small-Cell Lung Cancer in the KEYNOTE-010 Study. J. Clin. Oncol. 2020, 38, 1580-1590. [CrossRef] [PubMed]

82. Von Pawel, J.; Bordoni, R.; Satouchi, M.; Fehrenbacher, L.; Cobo, M.; Han, J.; Hida, T.; Moro-Sibilot, D.; Conkling, P.; Gandara, D.; et al. Long-term survival in patients with advanced non-small-cell lung cancer treated with atezolizumab versus docetaxel: Results from the randomised phase III OAK study. Eur. J. Cancer 2019, 107, 124-132. [CrossRef]

83. Watanabe, S.-I.; Nakagawa, K.; Suzuki, K.; Takamochi, K.; Ito, H.; Okami, J.; Aokage, K.; Saji, H.; Yoshioka, H.; Zenke, Y.; et al. Neoadjuvant and adjuvant therapy for Stage III non-small cell lung cancer. Jpn. J. Clin. Oncol. 2017, 47, 1112-1118. [CrossRef] [PubMed]

84. Kwiatkowski, D.J.; Rusch, V.W.; Chaft, J.E.; Johnson, B.E.; Nicholas, A.; Wistuba, I.I.; Merritt, R.; Lee, J.M.; Bunn, P.A.; Tang, Y.; et al. Neoadjuvant atezolizumab in resectable non-small cell lung cancer (NSCLC): Interim analysis and biomarker data from a multicenter study (LCMC3). J. Clin. Oncol. 2019, 37, 8503. [CrossRef]

85. Heymach, J.; Taube, J.; Mitsudomi, T.; Harpole, D.; Aperghis, M.; Trani, L.; Powell, M.; Dennis, P.; Reck, M. P1.18-02 The AEGEAN Phase 3 Trial of Neoadjuvant/Adjuvant Durvalumab in Patients with Resectable Stage II/III NSCLC. J. Thorac. Oncol. 2019, 14, S625-S626. [CrossRef]

86. Rothschild, S.; Zippelius, A.; Eboulet, E.I.; Savic, S.; Betticher, D.C.; Bettini, A.; Frueh, M.; Joerger, M.; Britschgi, C.; Peters, S.; et al. SAKK 16/14: Anti-PD-L1 Antibody Durvalumab in Addition to Neoadjuvant Chemotherapy in Patients with Stage IIIA(N2) Non-Small Cell Lung Cancer (NSCLC)—A Multicenter Single-Arm Phase II Trial. J. Clin. Oncol. 2020, 38, 9016. [CrossRef]

87. Liu, J.; O’Donnell, J.S.; Yan, J.; Madore, J.; Allen, S.; Smyth, M.J.; Teng, M.W.L. Timing of neoadjuvant immunotherapy in relation to surgery is crucial for outcome. OncoImmunology 2019, 8, e1581530. [CrossRef]

88. Gao, S.J.; Corso, C.D.; Wang, E.H.; Blasberg, J.D.; Detterbeck, F.C.; Boffa, D.J.; Decker, R.H.; Kim, A.W. Timing of Surgery after Neoadjuvant Chemoradiation in Locally Advanced Non-Small Cell Lung Cancer. J. Thorac. Oncol. 2017, 12, 314-322. [CrossRef]

89. Seymour, L.; Bogaerts, J.; Perrone, A.; Ford, R.; Schwartz, L.H.; Mandrekar, S.; Lin, N.U.; Litière, S.; Dancey, J.; Chen, A.; et al. iRECIST: Guidelines for response criteria for use in trials testing immunotherapeutics. Lancet Oncol. 2017, 18, e143-e152. [CrossRef]

90. Sepesi, B.; Godoy, M.; William, W.; Vaporciyan, A.; Lin, H.; Leung, C.; Lee, J.; Mitchell, K.; Weissferdt, A.; Le, X.; et al. P2.04-90 Nodal Immune Flare (NIF) Following Neoadjuvant Anti-PD-1 and Anti-CTLA-4 Therapy in Non-Small Cell Lung Cancer. J. Thorac. Oncol. 2019, 14, S745. [CrossRef]

91. Champiat, S.; Ferrara, R.; Massard, C.; Besse, B.; Marabelle, A.; Soria, J.-C.; Ferte, C. Hyperprogressive disease: Recognizing a novel pattern to improve patient management. Nat. Rev. Clin. Oncol. 2018, 15, 748-762. [CrossRef] [PubMed]

92. Necchi, A.; Bandini, M.; Calareso, G.; Raggi, D.; Pederzoli, F.; Farè, E.; Colecchia, M.; Marandino, L.; Bianchi, M.; Gallina, A.; et al. Multiparametric Magnetic Resonance Imaging as a Noninvasive Assessment of Tumour Response to Neoadjuvant Pembrolizumab in Muscle-Invasive Bladder Cancer: Preliminary Findings from the PURE-01 Study. Eur. Urol. 2020, 77, 636-643. [CrossRef] [PubMed]

93. McCracken, M.N.; Tavaré, R.; Witte, O.N.; Wu, A.M. Advances in PET Detection of the Antitumour T Cell Response. Adv. Immunol. 2016, 131, 187-231. [PubMed]

94. Goldberg, S.B.; Narayan, A.; Kole, A.J.; Decker, R.H.; Teysir, J.; Carriero, N.J.; Lee, A.; Nemati, R.; Nath, S.K.; Mane, S.M.; et al. Early Assessment of Lung Cancer Immunotherapy Response Via Circulating Tumour DNA. Clin. Cancer Res. 2018, 24, 1872-1880. [CrossRef]

95. Yang, C.-F.J.; Meyerhoff, R.R.; Mayne, N.R.; Singhapricha, T.; Toomey, C.B.; Speicher, P.J.; Hartwig, M.G.; Tong, B.C.; Onaitis, M.W.; Harpole, D.H.; et al. Long-term survival following open versus thoracoscopic lobectomy after preoperative chemotherapy for non-small cell lung cancer. Eur. J. Cardio Thorac. Surg. 2016, 49, 1615-1623. [CrossRef]

96. Ceylan, K.C.; Kaya, S.O.; Samancilar, O.; Gursoy, S.; Ucvet, A. The Effects of Neoadjuvant Chemotherapy on Pulmonary Structures: A Quantitative Analysis. Thorac. Cardiovasc. Surg. 2011, 60, 111-115. [CrossRef] 
97. Cerfolio, R.J.; Talati, A.; Bryant, A.S. Changes in Pulmonary Function Tests After Neoadjuvant Therapy Predict Postoperative Complications. Ann. Thorac. Surg. 2009, 88, 930-936. [CrossRef]

98. Leo, F.; Pelosi, G.; Sonzogni, A.; Chilosi, M.; Bonomo, G.; Spaggiari, L. Structural Lung Damage After Chemotherapy Fact or Fiction? Lung Cancer 2010, 67, 306-310. [CrossRef]

99. Rami-Porta, R.; Wittekind, C.; Goldstraw, P.; International Association for the Study of Lung Cancer (IASLC) Staging Committee. Complete Resection in Lung Cancer Surgery: Proposed Definition. Lung Cancer 2005, 49, 25-33. [CrossRef]

100. Caushi, J.; Ji, Z.; Zhang, J.; El Asmar, M.; Anagnostou, V.; Cottrell, T.; Chan, H.; Guo, H.; Merghoub, T.; Wolchok, J.; et al. P2.04-24 Transcriptional Profiling of Neoantigen Specific T Cells in Resectable NSCLC Treated with Neoadjuvant Anti-PD-1. J. Thorac. Oncol. 2019, 14, S717. [CrossRef]

101. Reuben, A.; Zhang, J.; Lin, H.Y.; Little, L.; Gumbs, C.; Tran, H.T.; Wang, L.; Haymaker, C.L.; Mehran, R.J.; Rice, D.C.; et al. T cell repertoire analysis of non-small cell lung cancer patients treated with neoadjuvant nivolumab alone or in combination with ipilimumab (NEOSTAR trial). J. Clin. Oncol. 2019, 37, 8532. [CrossRef]

102. Laza-Briviesca, R.; Cruz-Bermudez, A.; Casarrubios, M.; Nadal, E.; Molla, M.A.I.; García-Campelo, M.-R.; Huidobro, G.; Gomez, M.D.; Tarruella, M.M.; Abreu, D.R.; et al. Immune cell biomarkers on neo-adjuvant chemo-immunotherapy treatment for resectable stage IIIA NSCLC patients. Ann. Oncol. 2019, 30, v507. [CrossRef]

103. Slone, H.B.; Peters, L.J.; Milas, L. Effect of Host Immune Capability on Radiocurability and Subsequent Transplantability of a Murine Fibrosarcoma2. J. Natl. Cancer Inst. 1979, 63, 1229-1235. [CrossRef]

104. Golden, E.B.; Frances, D.; Pellicciotta, I.; DeMaria, S.; Barcellos-Hoff, M.H.; Formenti, S.C. Radiation fosters dose-dependent and chemotherapy-induced immunogenic cell death. OncoImmunology 2014, 3, e28518. [CrossRef] [PubMed]

105. Golden, E.B.; Apetoh, L. Radiotherapy and Immunogenic Cell Death. Semin. Radiat. Oncol. 2015, 25, 11-17. [CrossRef] [PubMed]

106. Aryankalayil, M.J.; Makinde, A.Y.; Gameiro, S.R.; Hodge, J.W.; Rivera-Solis, P.P.; Palayoor, S.T.; Ahmed, M.M.; Coleman, C.N. Defining Molecular Signature of Pro-Immunogenic Radiotherapy Targets in Human Prostate Cancer Cells. Radiat. Res. 2014, 182, 139-148. [CrossRef]

107. Nishikawa, H.; Sakaguchi, S. Regulatory T Cells in Tumour Immunity. Int. J. Cancer 2010, 127, $759-767$.

108. Diamond, J.M.; Vanpouille-Box, C.; Spada, S.; Rudqvist, N.; Chapman, J.R.; Ueberheide, B.M.; Pilones, K.A.; Sarfraz, Y.; Formenti, S.C.; DeMaria, S. Exosomes Shuttle TREX1-Sensitive IFN-Stimulatory dsDNA from Irradiated Cancer Cells to DCs. Cancer Immunol. Res. 2018, 6, 910-920. [CrossRef]

109. Vanpouille-Box, C.; Formenti, S.C.; DeMaria, S. TREX1 dictates the immune fate of irradiated cancer cells. OncoImmunology 2017, 6, e1339857. [CrossRef]

110. Bernstein, M.B.; Garnett, C.T.; Zhang, H.; Velcich, A.; Wattenberg, M.M.; Gameiro, S.R.; Kalnicki, S.; Hodge, J.W.; Guha, C. Radiation-Induced Modulation of Costimulatory and Coinhibitory T-Cell Signaling Molecules on Human Prostate Carcinoma Cells Promotes Productive Antitumour Immune Interactions. Cancer Biother. Radiopharm. 2014, 29, 153-161. [CrossRef]

111. Hettich, M.; Lahoti, J.; Prasad, S.; Niedermann, G. Checkpoint Antibodies but Not T Cell-Recruiting Diabodies Effectively Synergize with TIL-Inducing $\Gamma$-Irradiation. Cancer Res. 2016, 76, 4673-4683. [CrossRef] [PubMed]

112. Guerrera, F.; Tabbò, F.; Ruffini, E.; Bertoglio, P. Changing paradigms of non-small cell lung cancer treatment. J. Thorac. Dis. 2018, 10, S4170-S4172. [CrossRef] [PubMed]

113. Hishida, T.; Nagai, K.; Mitsudomi, T.; Yokoi, K.; Kondo, H.; Horinouchi, H.; Akiyama, H.; Nagayasu, T.; Tsuboi, M. Salvage surgery for advanced non-small cell lung cancer after response to gefitinib. J. Thorac. Cardiovasc. Surg. 2010, 140, e69-e71. [CrossRef] [PubMed]

114. Bott, M.J.; Cools-Lartigue, J.; Tan, K.S.; Dycoco, J.; Bains, M.S.; Downey, R.J.; Huang, J.; Isbell, J.M.; Molena, D.; Park, B.J.; et al. Safety and Feasibility of Lung Resection After Immunotherapy for Metastatic or Unresectable Tumours. Ann. Thorac. Surg. 2018, 106, 178-183. [CrossRef]

Publisher's Note: MDPI stays neutral with regard to jurisdictional claims in published maps and institutional affiliations. 